Andrews University

Digital Commons @ Andrews University

2010

\title{
A Program for Prevention and Intervention of Compassion Fatigue and Burnout Among Pastors in the Guyana Conference of Seventh-day Adventists
}

David O. McKenzie

Andrews University

Follow this and additional works at: https://digitalcommons.andrews.edu/dmin

Part of the Practical Theology Commons

\section{Recommended Citation}

McKenzie, David O., "A Program for Prevention and Intervention of Compassion Fatigue and Burnout Among Pastors in the Guyana Conference of Seventh-day Adventists" (2010). Professional Dissertations DMin. 516.

https://dx.doi.org/10.32597/dmin/516

https://digitalcommons.andrews.edu/dmin/516

This Project Report is brought to you for free and open access by the Graduate Research at Digital Commons @ Andrews University. It has been accepted for inclusion in Professional Dissertations DMin by an authorized administrator of Digital Commons @ Andrews University. For more information, please contact repository@andrews.edu. 


\begin{abstract}
A PROGRAM FOR PREVENTION AND INTERVENTION OF COMPASSION FATIGUE AND BURNOUT AMONG

PASTORS IN THE GUYANA CONFERENCE OF SEVENTH-DAY ADVENTISTS
\end{abstract}

by

David O. $\mathrm{M}^{\mathrm{c}}$ Kenzie

Adviser: Stanley Patterson 


\title{
ABSTRACT OF GRADUATE RESEARCH
}

Dissertation

\author{
Andrews University
}

Seventh-day Adventist Theological Seminary

\section{Title: A PROGRAM FOR PREVENTION AND INTERVENTION OF COMPASSION FATIGUE AND BURNOUT AMONG PASTORS IN THE GUYANA CONFERENCE OF SEVENTH-DAY ADVENTISTS}

Name of researcher: David O. $\mathrm{M}^{\mathrm{c}}$ Kenzie

Name and degree of faculty adviser: Stanley Patterson, Ph.D.

Date completed: February 2010

\section{Problem}

The membership of the Guyana Conference of Seventh-day Adventist has surged to over 50,000 over the ten year period, 1997-2006; however, the professional Adventist clergy group has experienced a decrease over the same time period—from thirty-three to twenty-seven ministers (Guyana Conference of SDA Statistics). The ratio of clergy to laity is, thus, $1: 1853$, where it was previously $1: 1039$. Consequently, ministers in the Guyana Conference of SDA are likely to become victims of burnout-and its compassion fatigue form - as they encounter the demands of ministry. 
Methods and Procedures

Following the case study method of qualitative research, the researcher utilized Eisner's (1998) self as an instrument theory. He suggested that there is valuable information to be gleaned when self is utilized, since each person's life experiences are unique. Thus, self as an instrument is not a disadvantage but an asset to research. In addition, Eisner (1998, p. 34) states that "the self is the instrument that engages in the situation and makes sense of it."

This project is designed to be utilized as a seminar consisting of six presentations for ministers. The researcher's personal experience-validated by collegial conversations was coupled with information gleaned from significant literature for the development of this seminar. The presentations, as they seek to educate ministers about these phenomena are accompanied by activities for participants to become involved in a practical way.

\section{Anticipated Outcomes}

The discussion and investigation of this phenomenon—-burnout, defined by Freudenberger and Richelson (1980) as "a debilitating psychological condition brought about by unrelieved work stress,, and its compassion fatigue form-which is associated with the physical, emotional/psychological, and mental price caregivers pay when attending to others who have experienced trauma or emotional aches (Figley, 1995a)revealed that ministers fall prey as a result of the simple fact that most people turn to their faith or religious beliefs when they are confronted with crisis or traumatic circumstances.

Thus, clergy are called upon in these times of personal, familial, and community stress. Also, ministers are faced with job stress as a result of the demands of the work 
defined by such factors as one minister pastoring numerous churches/members owing to the migration of many ministers.

i . After interaction with the information shared in each seminar, ministers will be more aware of the reality and dangers of these phenomena, and will be better equipped to prevent the same.

\section{Conclusion}

On the whole, the call to ministry is neither fleeting nor temporary; instead, it is permanent. It is the service of a lifetime. Health—both physical and spiritual--is needed for a minister to endure in this lifetime of service. S/he therefore cannot afford to work without pacing her/himself to finish the race. For this reason, the ministry calls for wise use of resources, not only those available in the form of human personnel who may be utilized through team ministry, but also the minister's energy.

As was noted earlier, this project contains tools that will equip the minister to be effective in ministry, while maintaining longevity; thus, burnout and compassion fatigue can be readily recognized and addressed so that ministers can continue to serve God's children effectively. 
Andrews University

Seventh-day Adventist Theological Seminary

\title{
A PROGRAM FOR PREVENTION AND INTERVENTION OF COMPASSION FATIGUE AND BURNOUT AMONG \\ PASTORS IN THE GUYANA CONFERENCE OF SEVENTH-DAY ADVENTISTS
}

\author{
A Project \\ Presented in Partial Fulfillment \\ of the Requirements for the Degree \\ Doctor of Ministry \\ by
}

David O. $\mathrm{M}^{\mathrm{c}}$ Kenzie

February 2010 
(C) Copyright by David O. $\mathrm{M}^{\mathrm{c}}$ Kenzie 2010 All Rights Reserved 


\title{
A PROGRAM FOR PREVENTION OF AND INTERVENTION FOR COMPASSION FATIGUE AND BURNOUT AMONG PASTORS IN THE GUYANA CONFERENCE OF SEVENTH-DAY ADVENTISTS
}

\author{
A project \\ presented in partial fulfillment \\ of the requirements for the degree \\ Doctor of Ministry
}

by

David O. McKenzie

APPROVAL BY THE COMMITTEE:

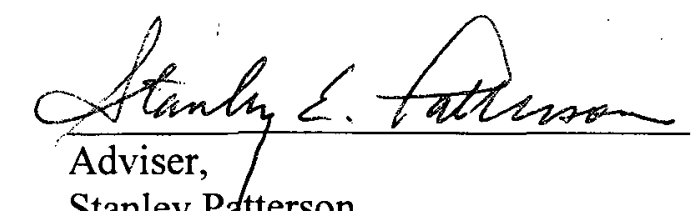

Stanley Patterson
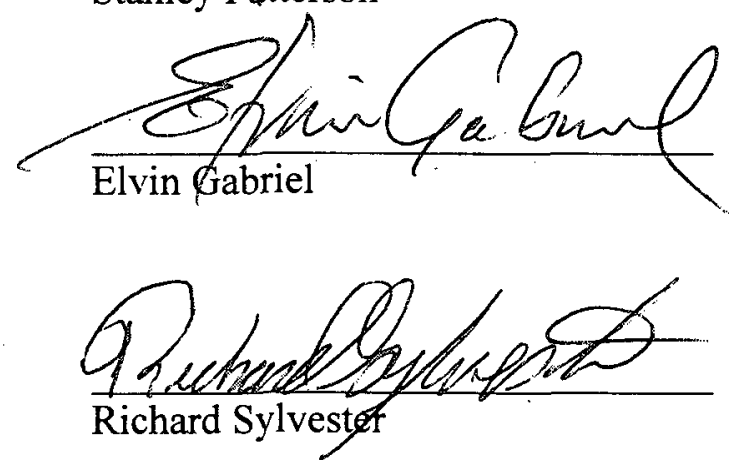

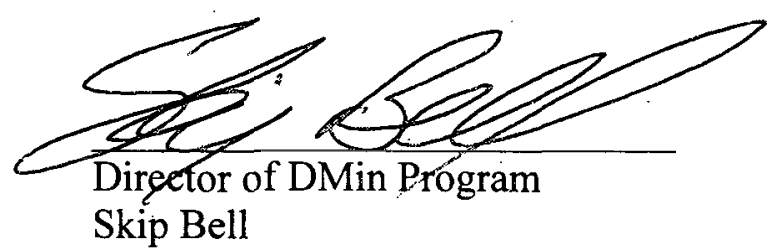

Degin is torthin

J. H. Denis Fortin

\section{Ce December 2012}

Date Approved 


\section{TABLE OF CONTENTS}

ACKNOWLEDGEMENTS $\ldots \ldots \ldots \ldots \ldots \ldots \ldots \ldots \ldots \ldots \ldots$ vi

Chapter

I.

INTRODUCTION $\ldots \ldots \ldots \ldots \ldots \ldots \ldots \ldots \ldots \ldots \ldots \ldots \ldots \ldots$

Statement of the Problem $\ldots \ldots \ldots \ldots \ldots \ldots \ldots \ldots \ldots \ldots$

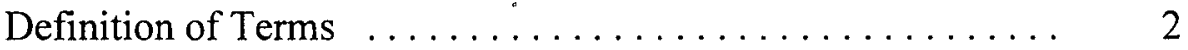

Statement of the Task ..................... 4

Justification for the Project . . . . . . . . . . . . . . . 4

Description of the Project Process $\ldots \ldots \ldots \ldots \ldots \ldots \ldots \ldots 4$

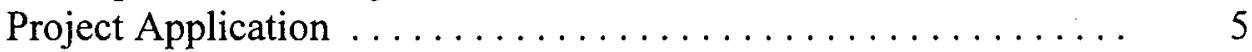

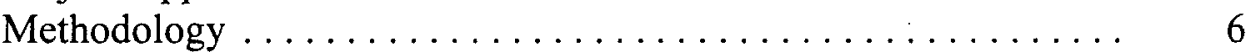

The Researcher as the Case Study Instrument $\ldots \ldots \ldots \ldots \ldots 6$

Historical Overview ...................... 7

Examination of Theological Concerns $\ldots \ldots \ldots \ldots \ldots \ldots 7$

Examination of Leadership Concerns $\ldots \ldots \ldots \ldots \ldots \ldots$

Overview of the Ministry Situation $\ldots \ldots \ldots \ldots \ldots \ldots \ldots$

Seminar Presentations $\ldots \ldots \ldots \ldots \ldots \ldots \ldots \ldots \ldots \ldots$

Limitations $\ldots \ldots \ldots \ldots \ldots \ldots \ldots \ldots \ldots \ldots \ldots \ldots \ldots \ldots$

II. A THEOLOGY OF BURNOUT $\ldots \ldots \ldots \ldots \ldots \ldots \ldots \ldots \ldots$

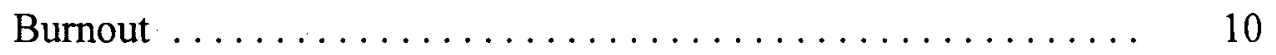

James White's Experience $\ldots \ldots \ldots \ldots \ldots \ldots \ldots \ldots \ldots \ldots$

Elijah's Experience ..................... 13

Elijah's Mt. Carmel Event $\ldots \ldots \ldots \ldots \ldots \ldots \ldots \ldots \ldots$

Signs of Burnout Exhibited by Elijah . . . . . . . . . 14

A Model for Preventing Burnout $\ldots \ldots \ldots \ldots \ldots \ldots \ldots$

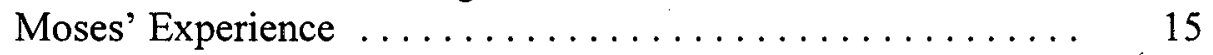

Acts 6 Model for Prevention of Burnout ............ 17

Involvement of the Church in Solving the Problem . . . . . 18

Delegation of Responsibility and Empowerment . . . . . . . 19

Jesus' Experiences: A Model for Preventing Burnout . . . . . . 20

Set Aside Time to be Alone ............... 21

Debrief with Coworkers .................. 23

Empowering Others $\ldots \ldots \ldots \ldots \ldots \ldots \ldots \ldots \ldots \ldots$

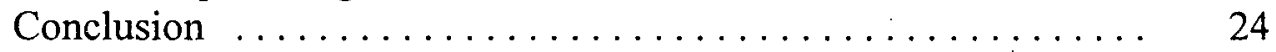


III. REVIEW OF RELATED LITERATURE AND RESEARCH

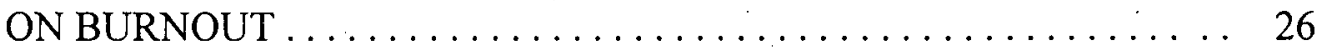

Development of the Concept of Burnout ................ 26

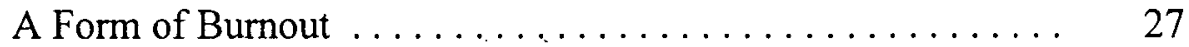

Burnout Among Clergy . .................... 30

Stages of Compassion Fatigue Contributing to Burnout ..... 32

Stages of Burnout ...................... 33

Characteristics of Burnout $\ldots \ldots \ldots \ldots \ldots \ldots \ldots \ldots, \quad 33$

Preventative Measures for Ministry . . . . . . . . . . 35

Leadership ........................... 35

Models of Leadership ........................ 36

Other Models . . . . ......................... 39

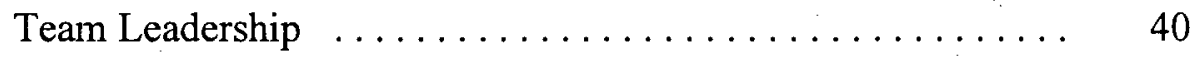

Virtual Teams ......................... 40

Time Management ....................... 41

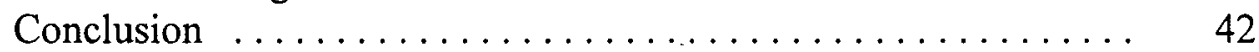

IV. MINISTRY CHALLENGES CONTRIBUTING TO BURNOUT IN THE GUYANA CONFERENCE OF SDA $\ldots \ldots \ldots \ldots \ldots \ldots, 44$

The Topography, Regions and Population, and the Economy ..... 44

Guyana Affected by Migration ................... 46

Brief History of the Growth and Leadership of the SDA

Church in Guyana ......................... 48

Guyana as a Mission ......................... 49

Guyana as a Conference ....................... 50

The Duties and Work Load of the Minister $\ldots \ldots \ldots \ldots \ldots \ldots$. 51

A Brief Summary of Burnout Experiences ............ 53

A Typical Day of the Minister-A Link to Causative

Factors for Burnout ...................... 55

Indicators of Burnout $\ldots \ldots \ldots \ldots \ldots \ldots \ldots \ldots \ldots \ldots \ldots$

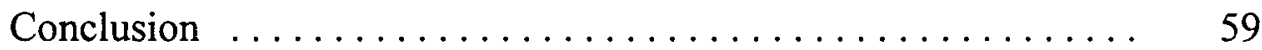

V. SEMINAR PRESENTATIONS $\ldots \ldots \ldots \ldots \ldots \ldots \ldots \ldots \ldots \ldots \ldots \ldots$

Effects and Impacts on the Pastor's Well-being, Implications for

Pastoral Leadership, Prevention of Burnout $\ldots \ldots \ldots \ldots \ldots .60$

Seminar Presentations Outline . . .............. $\quad 60$

Presentation 1: Overview and Signs/Symptoms of Burnout ...... 60

Introduction ............................. 60

Content of Presentation $1 \ldots \ldots \ldots \ldots \ldots \ldots \ldots \ldots \ldots \ldots \ldots \ldots$

Signs and Symptoms of Burnout $\ldots \ldots \ldots \ldots \ldots \ldots \ldots .62$

Presentation 2: Connecting Leadership Style and Burnout ...... 63

Introduction ........................... 63

Content of Presentation $2 \ldots \ldots \ldots \ldots \ldots \ldots \ldots \ldots$ 
Advantages and Disadvantages of Management and

Leadership within the Guyana Context $\ldots \ldots \ldots \ldots \ldots .66$

Presentation 3: Impact on Pastoral Ministry . . . . . . . . . . 69

Introduction ............................... 69

Content of Presentation $3 \ldots \ldots \ldots \ldots \ldots \ldots \ldots \ldots . \ldots 6 . \ldots 6$

Presentation 4: Strategies for Avoiding Burnout in Pastoral

Leadership ................................ 72

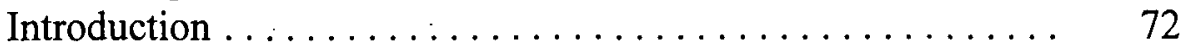

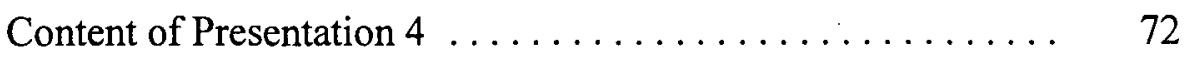

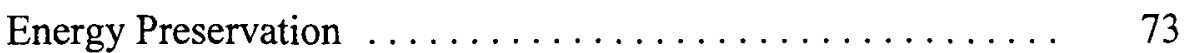

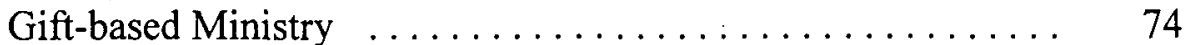

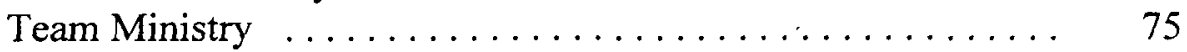

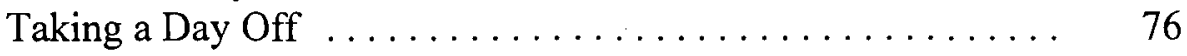

Vacation Time-Have Fun ..................... 78

Others' Expectations . . . . . . . . . . . . . . . . . 79

Presentation 5: Preventing Burnout through Enrichment of the

Spiritual Disciplines $\ldots \ldots \ldots \ldots \ldots \ldots \ldots \ldots \ldots \ldots \ldots \ldots$

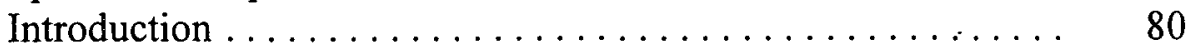

Content of Presentation $5 \ldots \ldots \ldots \ldots \ldots \ldots \ldots \ldots . \quad 81$

Presentation 6: Congregational Role for the Prevention of

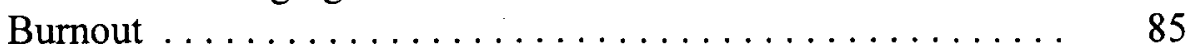

Introduction .......................... 85

Content of Presentation $6 \ldots \ldots \ldots \ldots \ldots \ldots \ldots \ldots \ldots$

Conclusion $\ldots \ldots \ldots \ldots \ldots \ldots \ldots \ldots \ldots \ldots \ldots \ldots \ldots \ldots \ldots$

VI. RECOMMENDATIONS AND CONCLUSION $\ldots \ldots \ldots \ldots \ldots . . \ldots 9$

Statement of Conclusion-General Issues $\ldots \ldots \ldots \ldots \ldots \ldots . \quad 89$

Expectations from Project . . . . . . . . . . . . . . . . . 90

Recommendations ........................... 95

Summary ............................. 98

Recommendations for Future Research $\ldots \ldots \ldots \ldots \ldots \ldots \ldots \quad 101$

Appendix

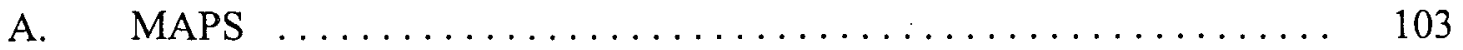

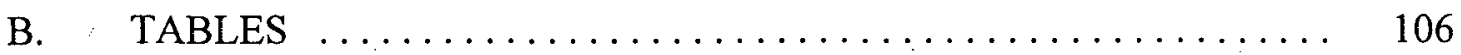

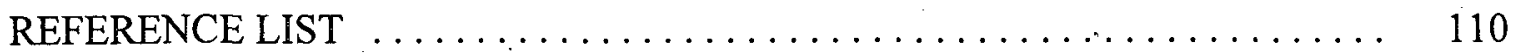

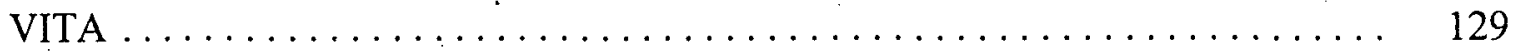




\section{ACKNOWLEDGMENTS}

This project has been realized through the input, support and encouragement of numerous individuals, as well as, peculiar circumstances which shaped the research and writing processes. Internal strength and wisdom were granted me from our Lord and Savior, Jesus Christ-my Captain, and consistent Guide throughout each stage of this undertaking.

Special thanks to all the professors who have shaped this project in one way or another-Dr. Stanley Patterson, my project advisor, for his advice and unfailing support throughout this process; Dr. Elvin Gabriel and Dr. Peter Swanson for their various editorial suggestions; and Dr. Kenneth Mulzac who served as my project advisor, giving erudite guidance - even on his sick bed. To all my professors, many thanks.

In addition, my gratitude is extended to Dr. Hilton Garnett, President of the Guyana Conference of SDA, and his Administrative Assistant, Ms. Marta Roberts, for their significant contributions toward the completion of this project. I also salute all my extended family, friends and colleagues in ministry, as well as church members who have 'held up my hands' during the extended period of research and writing.

Finally, special thanks to my life's companion and worthy teammate in ministry, Bernice Quashie-McKenzie, who supported me 'ad infinitum' throughout this process and continues to mentor our two lovely children, Nathanael and Nyah.

May the Light of Jesus be reflected through this work, as He continues to guide countless feet on the pathway to heaven. 


\section{CHAPTER 1}

\section{INTRODUCTION}

\section{Statement of the Problem}

The membership of the Guyana Conference of Seventh-day AdventistS (SDA) has, over the ten year period $1997-2006$, surged from 34,301 to 50,040 members. However, the professional Adventist clergy group has experienced a decrease, from 33 ministers to 27, over the same period (Guyana Conference of SDA Statistics). The ratio of clergy to laity is thus $1: 1853$, where it was previously $1: 1039$. There are approximately 187 churches spread across the country's 83,000 square miles, with one minister shepherding as many as fifteen congregations, some of which are separated by great distances and vast rivers.

Informal conversations reveal that many of these pastors show signs of low energy and exhaustion. The phenomenon of compassion fatigue, which is associated with the physical, emotional/psychological, and mental price caregivers pay when attending to others who have experienced trauma or emotional aches (Figley, 1995a, p. 4), and burnout, defined as the result of stress experienced on the job, and a condition that may encumber one's life personally and interpersonally, with negative impacts on general work performance (Freudenberger \& Richelson, 1980), haVE driven many ministers to seek other professions or leave the country permanently. Furthermore, Guyanese students studying in Trinidad and Tobago who observe this trend express little interest in 
returning to Guyana, thus reducing the number of available clergy to serve a growing church population.

\section{Definition of Terms}

The following definitions seek to provide specific meaning, clarification, and explication of the terms discussed in this project:

Compassion fatigue. Compassion fatigue is a state experienced by those helping people in distress. It is an extreme state of tension and preoccupation with the suffering of those being helped to the degree that it is traumatizing for the helper. It is a state of exhaustion and dysfunction — biologically, psychologically, and socially—as a result of prolonged exposure to stress (Figley, 1995, p. 253).

Burnout. "A state of physical, emotional and mental exhaustion caused by long term involvement in emotionally demanding situations" (Figley, 1997, p. 9).

It is important to note that the terms compassion fatigue and burnout are used interchangeably by various professionals. Figley $(2002$, p. 5) states that "compassion fatigue is one form of burnout. Family burnout is its interpersonal equivalent." The signs and symptoms of these phenomena are similar in several ways. There are seven areas in which the signs for both burnout and compassion fatigue are the same. These are cognitive, emotional, behavioral, spiritual, personal relations, somatic, and, work performance (Figley, 2002, p. 7).

Thus, for the purpose of this project, the term burnout is used to include both phenomena—burnout and compassion fatigue.

Leadership. "An influence relationship among leaders and followers who intend real changes that reflect their mutual purpose ...." (Rost, 1993, p. 145). 
Management. "An authority relationship between at least one manager and one subordinate who coordinate their activities to produce and sell particular goods and/or services" (Rost, 1993, p. 145).

Transactional Leadership. This type of leadership is carried out in the context of a transaction, and IS governed by the principle of exchanging one thing for another (Burns, 2003).

Transformational Leadership. Occurs when leaders engage in elevating the interests of subordinates, and create a transparent relationship that includes awareness and acceptance of the purposes and mission of the group, and inspirES them to look beyond their own interests toward team benefits (Bass, 1990).

Virtual Teams. Piccoli and Ives (2003, p. 365) defined virtual teams as "groups of geographically and/or temporally dispersed individuals brought together via information and telecommunication technologies".

Posttraumatic Stress Disorder (PTSD). This emotional illness in which victims suffer intense fear, helplessness, and re-experience of a traumatic event they had been exposed to (DSM-IV-TR, American Psychological Association, 2000).

Secondary Traumatic Stress. Secondary traumatic stress (STS) is defined as indirect exposure to trauma through another's firsthand account or narrative of a traumatic event (Zimering et al., 2003).

Vicarious traumatization (VT). The enduring psychological consequences for therapists of exposure to the traumatic experiences of clients. Persons who work with victims may experience profound psychological effects, which may be disruptive and painful for the helper. These effects can persist for months or years 
after working with a traumatized client (McCann \& Pearlman, 1990).

\section{Statement of the Task}

To design contextual seminars for SDA ministers in Guyana which would aid in the prevention of and recovery from burnout.

\section{Justification for the Project}

Isolated incidents of burnout have been an enduring issue in the Guyana Conference of Seventh-day Adventists. However, no formal research has been done to analyze the causative factors in order to provide preventive and curative measures as a resource tool for the ministers in the local conference.

Accordingly, after recognizing my personal need to anticipate burnout as a minister in the Guyana Conference of SDA, this project focus will advance my competence as a pastoral leader.

By the same token, the benefits of this project will surge outward from personal to collegial to corporal benefits. Fellow pastors as well as their families will experience an improved quality of life and relationships, and the SDA church body in the Guyana Conference will receive pastoral care from ministers who are not handicapped by burnout.

\section{Description of the Project Process}

A. The theological reflection centers on early Seventh-day Adventist leaders as well as on biblical leaders who exhibited the effects of burnout, as well as on strategies for prevention. First, James White's leadership; second, Jethro's counsel to Moses (Exod18); third, Elijah being worn out from service (1 Kgs 19); fourth, the appointment 
of the seven deacons in the early church (Acts 6); and fifth, Jesus' example of personal recharge time alone, and empowering others for team ministry.

B. Review and evaluate relevant literature. Books and other articles from a variety of sources, with examples of burnout in various professions, will be explored.

C. An overview of clergy work expectations in Guyana was compiled from my experience over six years while serving for separate pastoral districts.

D. Six seminars on burnout were developed and used in a series for ministers. Here, strategies for the prevention of and recovery from burnout will be developed and recommended for the Guyana Conference of Seventh-day Adventists.

E. Recommendations which include a model of leadership that best fits the Guyana context are made as the prevention burnout among ministers is advanced.

F. The project is scheduled for completion by the Fall Semester, 2009.

\section{Project Application}

This project first advocates ministers to make a personal and determined effort to balance ministry to others with their ministry to themselves, thus maintaining holistic health. In effect, as the pace of daily service is 'overhauled', ministers are encouraged to serve their first spiritual responsibility—-the home, their family.

Next, it is anticipated that pastors are committed to advancing their leadership and organizational competencies, which further motivates both laity and ministers to be more engaged in team ministry, toward the realization of shared visions.

On a conference level, this project provides an informed platform to the Guyana Conference of SDA towards an understanding of the effects of burnout on pastors, and recommendations for preventative and curative measures. 
It is anticipated that as ministers are motivated to serve with improved efficiency, the general health and effectiveness of pastors will improve, and thus positively impact their ability to serve the growth and mission of the church.

\section{Methodology}

This project utilizes the following methodology:

\section{The Researcher as the Case Study Instrument}

Following the case study method of qualitative research, the researcher utilized Eisner's (1998) self as an instrument theory. He suggested that there is valuable information to be gleaned when self is utilized, since each person's life experiences are unique: Thus, self as an instrument is not a disadvantage, but an asset to research.

In addition, Eisner (1998, p. 34) states that "the self is the instrument that engages in the situation and makes sense of it." Thus, he points out that "detachment and distance are no virtues when one wants to improve complex social organizations. It is important to know the scene.... It is impossible to understand the human pancreas, if it is studied without reference to the rest of the body" $(1998$, p. 2).

Self as the research instrument was also advanced by Piantanida and Garman (1999, pp. 139-140) who pointed out that the researcher as an instrument of inquiry is based on the "researcher's capacity for encountering, listening, understanding, and thus 'experiencing' the phenomenon under investigation."

Accordingly, the researcher's years of pastoral service, in addition to service as a lay evangelist and elder in the Guyana Conference of SDA, have provided the broad base of experiences needed for this project. 
Prior to professional studies for the ministry, the researcher worked closely and interacted with many ministers. Thereafter, in ministry, he fully came to terms with the extensive demands of service as he aligned himself with colleagues, experiencing the heavy workloads and the effects of ministry in Guyana. His hands-on experience as a minister and association with colleagues have yielded valuable information for this project.

\section{Historical Overview}

This involved the gathering of information from personal experiences and collegial conversations in addition to the Guyana Conference of SDA Statistics. With the resultant brief history of the enormous challenge with which ministers in the Guyana Conference are faced in the performance of their duties and a summary of burnout experiences, the researcher highlights the reduction in the Guyana ministry professionals, suggesting that heavy workload and burnout were contributing factors in ministers' migration.

\section{Examination of Theological Concerns}

The Scriptures along with Ellen G. White writings were examined and instructions and counsels relevant to this project were utilized. Particular attention was given to James White's experience of over work. Also, Jesus' example of balancing ministry demands and good health is highlighted.

Research and evaluation were made of applicable compassion fatigue and burnout literature. An overview of the numerous literature sources relating to the project topic was conducted. This review of literature includes the relationship between compassion 
fatigue and burnout and the origin of these terms and their impact on those involved in the helping professions.

\section{Examination of Leadership Concerns}

An examination of leadership theories was given, highlighting models of leadership that are influencing the minister's behavior and contributing to burnout in Guyana. This was accomplished through an examination of servant leadership, as well as transactional leadership, transformational leadership, and virtual teams.

\section{Overview of the Ministry Situation}

An overview was given of the demands of the typical minister's work day in Guyana and its impact on the ministers' ability to function effectively. This was done through an in-depth discussion of such areas as the topography, economy, work load, and the incurring factors that lead to ministers becoming burned out.

\section{Seminar Presentations}

The primary purpose of the six seminar presentations was to explore preventive measures and provide intervention for ministers who are prone to burnout. These seminars were designed to be conducted as lectures along with suggested interactive assignments.

\section{Limitations}

Given that burnout has a variety of effects-which are unique to each individual —one series of seminars is not expected to eliminate the incidence of this issue for ministers in Guyana. Instead, this project will serve as a part of the solution as initial 
awareness is heightened and ministers are more equipped to address this concern. Thus, these seminars apply the theory, but the ministers and administrators need to have their own encounters with the practical aspects of change.

Also, this project may have yielded more data for analysis had it been primary research conducted in Guyana-with a larger number of participants. A larger sample size. would yield numerous variables for consideration.

Furthermore, the time factor involved made it virtually impossible to conduct interviews in person. This project was done in the context of an intensive course of study. Accordingly, a project involving traveling and conducting such interviews would have exceeded the allotted time for this project. With these confines in focus, this project was limited to research, personal conversations, and the author's individual experiences as a full time minister in the Guyana Conference of SDA. 


\section{CHAPTER 2}

\section{A THEOLOGY OF BURNOUT}

The word burnout is not mentioned in the Bible nor in Ellen White's writings. However, signs and symptoms of these phenomena can be found among various characters in these writings.

The Bible and early Adventist history record numerous cases of burnout. However, the biblical and historical Adventist accounts this chapter examines will seek to establish the existence of this phenomenon. There are also biblical models which may serve as solutions to the behaviors contributing to burnout among Guyanese Adventist pastors. These accounts include the stories of James White, Moses and Jethro (Exod 18), Elijah (1 Kgs 18-19), the apostles (Acts 6), and the example of Jesus.

\section{Burnout}

\section{James White's Experience}

Among the founding fathers of the Seventh-day Adventist church is James White (1821-1881) who, by reason of his dedication and intense work to ensure the establishment of the SDA church and the spreading of its message, became a victim of burnout.

The fifth of nine children, he experienced early challenging years; however his motivation to succeed led to his ardent service to various communities and the Seventh- 
day Adventist church. He was a co-founder of the church, a President of the General Conference of Seventh-day Adventists, a minister, Bible preacher and teacher, an editor and writer, and an entrepreneur, among other areas of specialty.

He was married to Ellen Harmon on August 30, 1846. This union of thirty-six years produced four children in the midst of their tireless labor to ensure the growth and development of the Seventh-day Adventist church. In speaking about her husband's death in the book Retirement Years, Ellen said, "I felt that he had done his work. No one but myself knew how great a load he had carried in the efforts we had put forth to advance the truth. He had done the work of three men" (E. White, 1990, p. 164). Immediately after the fresh invigoration and new found faith in the Millerite movement, James began sharing the message in his early twenties as though he was the only one God could use. Ellen White (2003, p. 4) confirms, "In one six-week period, he gave his lecture series in twelve different churches, leading to the conversion of 1000 people."

The life and legacy of James White can be summed up in three main areas of the SDA church: an organizer/administrator, editor, and author. As an organizer/ administrator, among his major works, he served as the "founder and president of the Publishing Association in Battle Creek; the General Conference of Seventh-day Adventist; Battle Creek College; and the Pacific Press. In addition, he was the virtual founder of the Health Reform Institute" (E. White, 2003, p. 8).

He also made major contributions in the area of the publishing work. He served as founding editor of the following: Present Truth, the Advent Review (these two were combined into the Advent Review and Sabbath Herald); The Youth's Instructor; the Signs 
of the Times, and he also edited the Health Reformer. He can also be remembered as an author of numerous tracts and articles. It can be unmistakably stated that a full bibliography of his work numbers in the hundreds.

It is clear that James White labored intensely over the years to build the church to the heights that it enjoys today. This intense labor, however, was not without a cost. "Two decades of intense labor in building up the church claimed their toll when at age 44, he succumbed to a paralyzing stroke" (E. White, 2003, p. 7).

After a lengthy period of recovery, James White made the same mistake of overworking which resulted in the deterioration of his health and his eventual death. Knight (1993) noted that the later years of James' life were plagued by unstable physical and emotional health, as well as few periods of recovery, which were characterized by overwork. During this time, he endured four recurring strokes. On August 6, 1881, after contracting malaria and suffering another stroke, James White died.

James White was clearly a victim of job burnout. The Mayo Clinic Dictionary (2008, par. 3) defines burnout as "a state of physicál, emotional and mental exhaustion caused by long-term exposure to demanding work situations. Burnout is the cumulative result of stress."

As is seen in the life of James White, such exhaustion comes when the worker is so engaged in his work that he lacks balance between work and personal life. A worker's trying to carry the burden of the job alone, thus trying to be everything to everyone also contributes to burnout. Timothy Ponder (1983, p. 12) describes the victim of burnout as "hardworking and dedicated, sincere and loyal."

James White was indeed a dedicated and sincere worker; however, he did the 
work of many men by himself. Such a model of leadership is a sure recipe for burnout. It follows that such leaders soon become exhausted physically, mentally, and emotionally. E. White (2005, p. 105) reiterates the point when she highlights that "after my husband had been laid away in the grave, his friends thought of putting up a broken shaft as a monument. 'Never!' said I, 'never! He has done, singlehanded, the work of three men. Never shall a broken monument be placed over his grave!"

\section{Elijah's Experience}

According to Schaufeli, Maslach, \& Marek (1993), burnout usually follows moments of success or great achievement in the life of individuals who become victims. This is evident in the life of the ancient biblical character, Elijah. Elijah became a victim of burnout after celebrating moments of great success on Mt. Carmel. One authority aptly noted that after Elijah's mountaintop success, as recorded in $1 \mathrm{Kgs} 18$, he experienced a feeling of dejection, which is symptomatic of the result of intense effort, and adds that burnout commonly occurs subsequent to extreme experiences (Funk, 2005, Sec. 6, par. 1).

Elijah's experience is a case study that illustrates burnout for three major reasons: the intensity of his mission, the crisis attached to the circumstances, and performing a major task alone coupled with others' hatred directed toward him and his duties.

\section{Elijah's Mt. Carmel Event}

Elijah was a prophet of God who was fulfilling his calling on Mt. Carmel. His job was to represent God, and call others to revere Him as the only true God. In his service to God's people, in performing his ministry, he became a victim of burnout. 
Elijah's peak experiences all occurred on Mt. Carmel. The day was very exhausting spiritually, mentally, and physically. Even at the end of the day, Elijah is seen performing another overwhelming task — he ran before the King's chariots.

The distance Elijah ran before the king from Mt. Carmel to Jezreel must not be underestimated. While on Mt. Carmel, Elijah received the good news from his servant that a small cloud, which signaled the approaching rain, could be seen in the horizon after three years of drought. Gaebelein (1981, p. 147), highlighting the distance between Mt. Carmel and Jezreel, states, "Ahab's need for haste in the face of the oncoming cloudburst can be appreciated when one realizes that his chariot must travel seventeen miles to Jezreel through the accumulating mud and across the quickly swelling dry wadis." The Bible states that Elijah ran ahead of Ahab's chariot. This was certainly an exhausting day for Elijah.

In the single day on Mt. Carmel, Elijah's job took a toll on him physically, emotionally, and spiritually. The day's activities wore him out. The effects became evident after this experience in the form of his exhibiting the signs of burnout.

\section{Signs of Burnout Exhibited by Elijah}

Jezebel, after receiving an account of the day's events from Ahab, sent a message to Elijah. The message read, "Let the gods do to me, and more also, if I make not thy life as the life of one of them by tomorrow about this time" (1 Kgs 19:2). Upon receiving the message, Elijah "arose, and went for his life, and came to Beer-sheba, which belongeth to Judah, and left his servant there" (1 Kgs 19:3).

Shortly after Elijah's peak moments of-achievements and exhaustion, he experienced burnout. This was evident in the stress-related signs that he exhibited. Funk 
(2005, Sec. 6, par. 2), listed nine "stress-related characteristics Elijah exhibited during this period:

1. Rejection (v. 2).

2. Detachment (he ran away from everyone, v. 3 ).

3. Exhaustion (physically, vv. 5-6, mentally, emotionally and spiritually).

4. Suicidal thoughts (an advanced stage of the depression and despair that result from burnout, v. 4).

5. Bitterness (he reminded God of how zealous he had been, v. 10).

6. Feelings of being indispensable (v. 10).

7. Feelings of being mistreated (v. 10).

8. Feelings of self-pity (v. 10).

9. Feelings of persecution-he felt put upon and became increasingly suspicious of his environment.

\section{A Model for Preventing Burnout}

In providing therapy to victims of burnout and compassion fatigue, the example of God in attending to Elijah provides a perfect model. Funk (2005, Sec. 6, par. 3) listed four steps God used in ministering to Elijah:

1. God provided time for sufficient rest and proper nourishment (vv. 5-6).

2. God offered a quiet time for Elijah (v. 12).

3. God gave him an assignment that he was capable of fulfilling (v. 16)

4. God provided a sense of companionship (v. 1'8).

\section{Moses' Experience}

Moses' type of leadership prior to receiving advice from Jethro was one that promoted the onset of burnout. Moses was appointed by God to lead the children of Israel to the Promised Land. He was to function as their mediator and teacher of God's decrees and laws. His method of leadership in the day-to-day life of the Israelites during their sojourn in the wilderness was one which established him as the sole person in charge, the chief.

He was virtually trying to attend to the needs of the people and provide leadership 
all by himself. Moses sat to judge the people from the morning unto the evening. Moses' father-in-law said, "What is this thing that thou doest to the people? Why sittest thou thyself alone, and all the people stand by thee from morning unto even?" (Exod 18:13-14).

The passage begins by highlighting the fact that the particular day in question was the day after Moses' father-in-law came as his guest. One would think that Moses would, therefore, spend time with his guest. Mackay (2001, p. 315) notes that "the next day probably serves to show that the pressure that had built up on Moses was so severe that even the arrival of his father-in-law did not permit any significant break in his daily routine."

Thus, it can be inferred that attending to the needs of the people from morning to evening was a typical day for Moses. He was yielding to the temptation of over-doing, and over-caring for the people, which would have resulted in his becoming exhausted. This type of leadership certainly leads to burnout.

It took the eye of an outsider-Jethro, to detect the danger of Moses' model of leadership and to suggest a simpler model. Jethro saw how such a situation was unsustainable and that, should it continue, it would be disastrous for Moses. In the electronic Matthew Henry Bible Commentary, 2006, Notes: Exod 18:14), Henry stated that Jethro thought it was too much business for Moses to undertake alone, that it would be a prejudice to his health and too great a fatigue for him.

Jethro suggested a leadership method that is based on division of labor. Thus, Moses was asked to empower others, to guide others toward embracing empowerment. He was to identify capable men with leadership qualities, and empower them to do the 
work. "Great men should not only study to be useful themselves, but contrive how to make others useful, according as their capacity is" (Matthew Henry Bible Commentary, 2006, Notes: Exod 18:21).

It follows that such a distribution of responsibility aided in preserving Moses' health and allowed him the opportunity to attend to matters that others may not have been able to. Also, those being served were better attended to. "If all focuses on one individual, not only is he liable to be overwhelmed by the strains, but others will weaken and become weary because of the delays inherent in one man trying to control every aspect of a complex situation" (Mackay, 2001, p. 320).

Moses' new model of leadership is an effective model to be utilized in the prevention of burnout. It helps to protect leaders from excessive stress and overexhaustion, which are contributing factors to burnout.

Acts 6 Model for Prevention of Burnout

The latter section of Acts chapter 4 (Acts 5:33-37) indicates that the early church encountered a major problem. Believers became destitute as a result of accepting Christ and becoming members of the church. In an attempt to solve this problem, a communal approach was adopted. The believers sold their land and brought the gains to the apostles. The Bible states, "Distribution was made unto every man according as he had need" (Acts 4:35).

Furthermore, Acts chapter 6 tells us that this plan encountered some additional problems. Here, the Hebrews were accused by the Grecians (Hellenists) of being prejudiced in the distribution of the gains. The claim was that the Grecian widows were 
being overlooked. Gaebelein (1981, p. 330), in highlighting contributory factors to this problem states,

Apparently with the "increasing" number of believers and with the passing of time, the number of Hellenistic widows dependent on relief from the church became disproportionately large. Many pious Jews of the diaspora had moved to Jerusalem in their later years in order to be buried near it, and their widows would have had no relatives near at hand to care for them as would the widows of the longtime residents. Nor as they became Christians would the 'poor baskets' of the national system of relief be readily available to them. So the problem facing the church became acute.

The method utilized by the apostles to alleviate this problem can serve as a model to prevent leaders' burnout. The three steps of the model are (a) the entire church was involved in the solution, (b) the delegation of responsibility, and (c) empowerment of those elected to serve.

\section{Involvement of the Church in Solving the Problem}

The apostles did not think of solving the problems themselves, but rather sought the input and support of the body of believers. Thus, they took the problem to the church. Gaebelein (1981, p. 331) states, "The apostles made a proposal, but the church, the community of God's Spirit, made the decision."

Pastoral leaders will serve themselves well if they refrain from functioning as the exclusive authority figure, taking solely upon themselves the responsibility to solve every problem. Problem solving must be all inclusive, that is, it must be the responsibility of the entire body of believers. The Seventh-day Adventist Bible Commentary, volume 6 (p. 187) states, "The twelve placed the responsibility squarely upon the shoulders of the believers, who were to make a choice from among their number. 


\section{Delegation of Responsibility and Empowerment}

In support of this practice, the Seventh-day Adventist Bible Commentary, volume 6 (p. 189) also concurs, "When the apostles heard the complaints, and realized their seriousness, they did not pause, apparently, to vindicate themselves. They acted promptly. They may have remembered the precedent set by Moses (Exod 18:25), and like him, they resolved to delegate authority.. The biblical account tells us that the church selected seven deacons with the responsibility to take care of the distribution of the various offerings and other contributions to the appropriate individuals.

Consequently, the disciples had opportunity to commit themselves "continually to prayer, and to the ministry of the word" (Acts 6:4). The seven men, therefore, were accountable for such matters as the "serving of tables" (Acts 6:2-3). The seven men were to be the deacons of the church even though the word deacon was not used. However, it refers to their appointed duty which was to distribute the daily aid. Both the apostles and the deacons were involved in the ministry of the church with distinct responsibilities.

It is essential to note that the Greek word used to describe both the apostles' duties (ministry of the word) and that of the seven deacons (distribution of aid) is the same word-"diakonia." Therefore, this term suggests that though their job descriptions varied, both the apostles and deacons had similar responsibilities and commitments which hinged upon service to God's people.

This delegation of responsibility aids in preventing leaders' experience of both qualitative and quantitative overload which are contributors to burnout. Ponder (1983, p. 48) affirms,

...there is qualitative overload where the job assignment demands more extensive 
skills, abilities and knowledge than the person has. Quantitative overload also exists, where the worker simply has too much to do within the allotted time on the job. Both of these overload conditions lead to stress, which in turn blossoms into the worker's burnout.

In empowering those elected to serve, the apostles bestowed on the seven deacons the full authority to perform their duties. Gaebelein (1981, p. 331) states:

The apostles therefore laid their hands on the seven and appointed them to be responsible for the daily distribution of food. The laying on of hands recalls Moses' commissioning of Joshua in Numbers 27:18-23, where through this act some of Moses' authority was conferred on Joshua. That is evidently what the laying on of hands was meant to symbolize here, with the apostles delegating their authority to the seven selected by the church.

\section{Jesus' Experiences: A Model for Preventing Burnout}

Jesus' model of leadership is a perfect example of a style that also assists in the prevention of burnout. The foundation tenets of this model include empowering others and team ministry.

Funk (2005, Sec. 1. par. 4) explains that the compassion fatigue form of burnout is the emotional scum that results from the experience of service to the suffering. Especially when ministering to individuals in adverse conditions, it is a 'compassionconsuming calling'.

During his earthly ministry, Jesus Christ was exposed to the contributing factors that cause burnout. He can be placed into the category of those who are most likely to suffer from this phenomenon. Funk (2005, Sec. 3, para. 2) emphasizes that the people who are most prone to this phenomenon are

Those who work with people who are in need, who are hurting, who have special problems going on in their lives and who have significant health issues; therefore, you are basically vulnerable to being overwhelmed by their experience as you absorb the trauma through their eyes and ears. 
Jesus attended to and healed countless sick individuals. The Bible records reveal that the number of the sick that were healed cannot even be numbered. In an attempt to communicate the number of individuals who received healing from Jesus, apart from those named, the Bible employs the following phrases: crowds in Judea (Matt 21:14); crowd in Galilee (Matt 9:35); many in Jerusalem (Matt 21:14); great multitudes and many others (Matt 15:30); few in Nazareth (Mark 6:1-6); many at sunset (Luke 4:40-41), among others (Palmer, 2006). The sick presented themselves with a variety of illnesses, including leprosy, palsy, and in some cases, even death was attended to.

Attending to the sick and the needy was a major component of Jesus' ministry.

His entire earthly ministry was spent in service to the sick. E. White $(1877$, p. 226) attests

Jesus healed many and various cases of bodily disease, while he was preaching and ministering to sin-sick souls. Many hearts were liberated from the cruel bondage of sin. Unbelief, discouragement, and despair, gave place to faith, hope, and happiness. But when the sick and wretched applied to the Savior for help, he first relieved the poor, suffering body before he attempted to minister to the darkened mind. When the present misery of the suppliant was removed, his thoughts could better be directed into the channel of light and truth.

It must be noted that Jesus was greatly exposed to the factors which contribute to burnout, and he exhibited preventive practices. McHolm (2006, pp. 12-15) lists a number of preventive and recovery guide lines for burnout. Among these guidelines are two of the major practices of Jesus: setting aside time to be alone and debriefing with coworkers. Another preventive measure that will be discussed is Jesus' empowerment strategy.

\section{Set Aside Time to be Alone}

Each day, Jesus took breaks from His ministry of attending to the wounded. 
During His private moments, He devoted time to self care, conveying His thoughts to His Father, and regaining the energy He had exhausted in attending to the broken. In one example, of this after the multitudes flocked to him for healing and the fulfillment of other needs, he withdrew for private time. "And when he had sent the multitudes away, he went up into a mountain apart to pray: and when the evening was come, he was there alone" (Matt 14:23).

Thus, it is evident that Jesus daily spent time alone for self care. "And in the morning, rising up a great while before day, he went out, and departed into a solitary place, and there prayed" (Mark 1:35).

The Bible also tells of His teaching his disciples to spend time alone, away from even the people they are called to serve in an effort to recover from physical exhaustion. In Bethsaida, just before Jesus fed the five thousand, He took the disciples apart into a solitary place to rest—even though the crowds were following Him. "And the apostles, when they were returned, told him all that they had done. And he took them, and went aside privately into a desert place belonging to the city called Bethsaida" (Luke 9:10).

Jesus purposefully took time off from the people He served for time alone. It was never easy for Him to do so, taking into account that crowds always followed Him however; He made it His duty to do so. A clear example of this is when $\mathrm{He}$ and His disciples rested privately in Bethsaida. The Expositor's Bible Commentary (Notes: Luke 9:10) states, "It was often not possible for Jesus to escape the crowds even when it was possible for him to leave a place." Here, it must also be noted that even though the crowd was following, and waiting for Him, He took His disciples apart for time alone in rest and renewal. 


\section{Debrief with Coworkers}

Jesus spent time recapping the daily activities with his disciples. "And the apostles gather themselves together unto Jesus, and told him all things, both what they had done, and what they had taught" (Mark 6:30). In clarifying this case in point, the Expositor's Bible Commentary (Notes: Mark 6:30) states, "The disciples had just returned from what was apparently an intensive mission. Since they were doubtless tired from their missionary activities and from the demands of the crowds, Jesus decided to seek rest for them."

This passage indicates that Jesus and his disciples spent quality time doing two things: resting; and sharing and analyzing their daily experiences. Such a practice is significant toward avoiding burnout since there is the opportunity to bounce ideas and experiences off other members in the support network.

\section{Empowering Others}

Jesus empowered the disciples to be coworkers with him and to carry on the work, even in his absence. "And he called unto him the twelve, and began to send them forth by two and two; and gave them power over unclean spirits" (Mark 6:7). Hence, John Gill's Exposition of the Bible (Notes: Mark 6:7) states, "his twelve disciples . .., he now called them to him, and gave them their commission, qualifications, and instructions."

Additionally, the John Darby's Synopsis of the New Testament highlighted the fact that Jesus who was all-powerful made sure that His disciples were fully equipped for their ministry assignments; they were even empowered to stand against demons. 
Jesus did three main things: He called them, empowered them, and sent them. In calling them, He taught them:

Hitherto they had been conversant with Christ, and had sat at his feet, had heard his doctrine, and seen his miracles; and now he determines to make some use of them; they had received, that they might give, had learned, that they might teach; and therefore now he began to send them forth (Matthew Henry Bible Commentary, 2006, Notes: Mark 6:7).

He empowered them. The Greek word used for power is "exousia." It is power of authority. He gave them the power He possessed so they do what He did.

He sent them out. Notice that Jesus focused on team ministry. Jesus was not only preventing burnout for Himself, but also for His disciples. He was teaching them to depend on each other and work together toward the accomplishment of the goals for a shared vision. E. White (2005, p. 350$)$ adds that the disciples were therefore able to "help and encourage each other, counseling and praying together, each one's strength supplementing the other's weakness."

\section{Conclusion}

The concepts of burnout guide ministers on a fundamental route, advancing the awareness of the stress and great responsibilities implicit in service to others. Ministers of religion are called to a life of fulltime ministry in which they minister to the physical, spiritual, and emotional needs of others. Thus, the minister is always on call fulfilling his/her responsibility of shepherding, nurturing, and attending to the needs of the wounded. These expected duties make the minister vulnerable to the phenomenon of burnout.

In effect, the experience of Moses and his father-in-law, Jethro, clearly conveys the fact that effective spiritual leaders, in an effort to guard their health and illustrate 
God's desire of inclusivity in leadership, do not lead single-handedly, but by delegation of responsibilities. Jesus' model, which included withdrawal from the demands of others and personal time for self repair, also presents another major element in the life of the minister for the prevention of burnout.

Furthermore, reflecting on the basketball metaphor, we learn that we are suited to play some positions more than others, and we put our talents to use where we will be of most use and derive the greatest satisfaction.

- One significant thing is that pastoral ministry possibly gives an opening for personal development. This, in turn, is beyond what can be realized on an individual basis because it facilitates the sharing of the experiences of countless others. Whether this sharing produces negative or positive results, the relationships formed add to the 'wholeness' of each minister. 


\section{CHAPTER 3}

\section{REVIEW OF RELATED LITERATURE AND RESEARCH ON BURNOUT}

\section{Development of the Concept of Burnout}

Burnout first emerged as a social problem instead of an academic construct. The first few articles about burnout appeared in the mid-1970s in the United States. These articles provided an initial description of the phenomenon, gave it a name, and went on to identify how common it is/was in society (Schaufeli, Maslach, \& Marek, 1993).

Burnout embraces a social origin as it was studied and developed by Freudenberger, a psychiatrist who worked at an alternative health care facility and Maslach, a social psychology researcher. Later studies have been conducted to analyze various contributors to burnout such as post traumatic stress disorder, a processing dysfunction, which has been noted to be a factor in the development of burnout over time (Brattberg, 2006).

American workers have also become increasingly disconnected and alienated from their communities and increasingly insistent to attain personal fulfillment and gratification from their work. Thus, many workers have higher expectations of fulfillment and fewer resources to cope with frustrations and work stressors (Schaufeli, Maslach, \& Marek, 1993).

Thus, Freudenberger and Richelson (1980, p. 13) states, "a burn out is someone in 
a state of fatigue or frustration brought about by devotion to cause, way of life, or relationship that failed to produce the expected reward". Thus, when the expectation level is dramatically opposed to reality and the person persists in trying to reach that expectation, complications arise:

During the 1980s, the concept of burnout took on a more focused and empirical perspective; standardized measures of burnout were developed, thus researchers had more precise definitions and tools for studying burnout amidst the variety of characteristics and forms.

\section{A Form of Burnout}

Compassion fatigue is a concept born out of post-traumatic stress and is a "form of burnout" (Figley, 2002, p. 5). In our post-modern society, numerous professional helpers are overworked, work nonstandard hours, and are even seeking to quicken the pace of their labor (Perry-Jenkins, Repetti, \& Crouter, 2000). Those who are employed with or around trauma, such as social workers, counselors, clergy or health care personnel, may be at greater risk of experiencing compassion fatigue which involves the difficulty of being in harm's way while needing to act with compassion (Stamm, 2002).

Professionals in helping professions such as therapists, social workers, and clergy are frequently listening to the stories of victimized individuals or traumatized communities. Primary traumatic stress is the term used for individuals who respond with intense fear or helplessness after experiencing a traumatic event firsthand.

Secondary traumatic stress (STS) occurs as a result of indirect exposure to trauma through a firsthand account or narrative of a traumatic event (Zimering, Munroe, \& Gulliver, 2003). 
According to McCann and Saakvitne (1995), traumatic tension may be caused by the impact of life-threatening situations, physically challenging activities, great material ruin, severe injury, and sexual or other physical assault. They may be experienced as one-time incidents, such as a natural disaster, house fire, violent crime, or airplane accident, or they may be ongoing, repetitive, and unrelenting, as is often the case in spousal separations, divorce, combat or war. Child abuse and neglect, and other forms of domestic violence are additional examples of this. Most often, traumatic events are accompanied by several losses and are relatively common.

In various cases, these experiences induce multiple psychological and physiological stress reactions. Such events may be appalling and emotionally overwhelming, and it is likely that people who experience them, directly or indirectly, will exhibit several reactions (Boscarino, Figley, \& Adams, 2004).

Reactions to traumatic events vary considerably, ranging from relatively mild, creating minor disruptions in the person's life, to severe and debilitating. It is very . common for people to experience anxiety, terror, shock, and upset, as well as emotional numbness and personal or social disconnection (Boscarino, Figley, \& Adams, 2004, pp. $16,17)$.

In contrast to primary stress symptoms, which are directly related to the experience of primary traumatic stress as a victim, secondary stress is defined as "the natural consequent behaviors and emotions resulting from knowing about a traumatizing event experienced by a significant other-the stress resulting from helping or wanting to help a traumatized or suffering person" (Pearlman \& Saakvitne, 1995, p. 156).

Thus, the concept that trauma can occur indirectly is consistent with The 
Diagnostic and Statistical Manual of Mental Disorders, $4^{\text {th }}$ ed. (p. 464), criterion A for posttraumatic stress disorder (PTSD that asserts that "traumatization is possible without being personally harmed or threatened with harm. Traumatization can occur through contact with narratives of primary traumatic stress."

It follows that the adverse psychological consequences of working primarily with traumatized individuals have been described in various ways: secondary traumatic stress disorder (STSD), compassion fatigue, and vicarious traumatization (McCann \& Pearlman, 1990; Pearlman \& Saakvitne, 1995).

This psychological morbidity may often be overlooked until more serious consequences, such as clinical depression, anxiety, substance dependence, burnout, or post traumatic stress disorder (PTSD) become evident. Frequent interactions with survivors of trauma may possibly increase the likelihood of developing STSD (Figley, 1995). Furthermore, an Australian study done in 2002 found that $27 \%$ of the community mental health case managers who worked with traumatized clients experienced extreme distress. Another study of Oklahoma City trauma workers also found that $64.7 \%$ of them suffered from symptoms of PTSD (Wee \& Meyers, 2002).

As data from the response to the World Trade Center attacks were analyzed, one of the initial studies stated that a substantial proportion of clergy and others in the tri-state New York area are at significant risk for the compassion fatigue form of burnout (Roberts, Flannelly, Weaver, \& Figley, 2003, p. 758). Results of the Compassion Satisfaction and Fatigue Test (Figley, 1995) among 9/11 responders found the following levels of compassion fatigue: extremely high, $27.5 \%$; high, $11.7 \%$; and moderate, $15.4 \%$. 


\section{Burnout Among Clergy}

Most individuals turn to their faith when they face crisis or traumatic

circumstances. Clergy are at the forefront in times of personal, familial, and community stress. Thus, many ministers are called upon in crisis situations associated with grief, depression, or trauma reactions such as personal illness or injury, death of a spouse, close relative, or friend, divorce or marital separation, or serious family health issue. The New England Journal of Medicine (p. 1509) reported that $90 \%$ of Americans turned to religion as a coping reaction to the terrorist attacks on September 11 .

In this, our post-modern society, numerous professional helpers are seeking to accelerate the rate of their labor, are being overtaxed, and are working atypical hours (Perry-Jenkins, Repetti, \& Crouter, 2000). The work of clergy is no exception, and this is further confounded by the social desirability factor or the assertion that pastors are more reluctant to admit when they are feeling overloaded (Rayburn, Richmond, \& Rogers, 1986).

Ever since the 1960 s, issues surrounding work, stress, and family have emerged prominently in research literature (Myers \& Booth, 1999; Patterson, 2002; Suárez \& Baker, 1997; Walsh, 2002). In particular, studies on the work stress of pastors have indicated that members of the clergy not only experience distinctive stressors related to their careers-counseling individuals and families, teaching, guiding, and carrying out administrative responsibilities — but that these stressors may also intensify the impact of such efforts on their personal lives.

Those who work with or around trauma, such as clergy or health care workers,

often encounter compassion fatigue, which involves the difficulty of being in harm's way 
while needing to act with compassion (Stamm, 2002). Burnout, which is associated with stress and hassles on the job, is very cumulative, is relatively predictable and frequently a vacation or change of job helps a great deal (Lehr, 2006).

Lehr (2006, p. 3) suggests that many pastors are experiencing pain in ministry. "That is to say, the very practice of parish ministry had become painful for them." These ministers, even though veterans in ministry, are struggling "to find a way to serve the church without all that pain, a pain in which they lack any significant understanding as to its source or its course." All of these ministers are desirous of learning how "to serve faithfully without losing their minds, their families, and even their souls." In addition, a recently conducted national survey (2001) of 2,500 religious leaders by-Duke Divinity School, found that $40 \%$ percent of ministers are depressed and worn out (Wells, 2002). Though there is little research done on burnout in general in Guyana, there is evidence that ministers in Guyana are stressed in various ways and need to be equipped with coping mechanisms. This is vital, since many ministers are not trained to be counselors.

Whereas professional therapists, as part of their training, are usually informed about the psychological effects of working with clients in crisis, and are given ways to proactively deal with stress, clergy are rarely given this training.

Furthermore, when four out of ten people in the US who experience mental health problems first seek assistance from the clergy instead of from psychologists, psychiatrists, social workers, or counselors (Weaver et al., 1997; Weaver, Koenig \& Revilla, 2001), the consequences of counseling relationships on clergy should be a potent issue to be addressed. 
In Guyana, a third world country, where professional therapists are not popular, , it will not be surprising to show that most of the population turn to spiritual leaders when in crisis. Informal interviews with members of the public revealed that when asked which professional they might turn to for help with emotional problems, clergy were identified ahead of both primary care physicians and other mental health personnel. In general, pastoral counseling for an emotional problem is seen as far less stigmatizing then a visit to a mental health professional. Another advantage noted is that it is usually free of cost.

\section{Stages of Compassion Fatigue Contributing to Burnout}

According to Reynolds (1999, p. 10), clergy and other caregivers may find themselves at different levels or stages of compassion fatigue depending on the intensity of the care-giving relationship and their own personal resources. The three major stages of compassion fatigue presented include:

Stage 1: The clergy/caregiver may feel irritated, frustrated, slightly depressed, and apathetic;

Stage 2: As the level of care giving intensifies, a clergy/caregiver may feel trapped and experience loss of sleep, change in eating habits, regressive behaviors, and a strong desire to be alone.

Stage 3: The clergy/caregiver experiences a tremendous amount of pain and anxiety in the care-giving relationship and cannot escape it. This is the most extreme phase of compassion fatigue, which is characterized by physical problems, escape fantasies, and debilitating depression. 


\section{Stages of Burnout}

In discussing the occurrence of this phenomenon, Staton, et. al (2007, pp. 356357) identifies four stages of burnout:

Stage 1 -Enthusiasm: In this stage, workers enter the job or task with unrealistic expectations regarding the outcome. They expect to realize far more than is practical because of their optimistic visions for the situation.

Stage 2 - Stagnation: Stagnation begins when the worker starts to feel that personal, financial, or career needs are not being met, and that the personal effort he or she has expended is not being met with satisfactory results.

Stage 3 - Frustration: Frustration refers to the point where the worker begins to question his or her effectiveness.

Stage 4-Apathy: "The apathy stage represents full burnout." The worker is in a stage of disequilibrium and immobility. There is little awareness of what is happening and she or he may defy any attempts at intervention.

\section{Characteristics of Burnout}

It has been noted that the most conscientious people-helpers are most vulnerable to burnout. Those affected include counselors, clergy, social workers, child advocates, child protective service workers, mental health professionals, psychologists, lawyers, disaster relief workers, medical doctors, nurses, teachers, police officers, firefighters, and shelter workers (Beaton \& Murphy, 1995).

Maslach (1993, pp. 19-32) offers the following signs:

(1) decreased energy - 'keeping up the speed' becomes increasingly difficult;

(2) feeling of failure in vocation; 
(3) reduced sense of reward in return for pouring so much of self into the job or project;

(4) a sense of helplessness and inability to see a way out of problems; and

(5) cynicism and negativism about self, others, work and the world generally.

Some of the other symptoms and human costs of burnout include increased negative arousal, intrusive images of member's/clients' traumas, diminished sense of purpose with career, difficulty separating work life from personal life, lowered frustration tolerance, dread of working with certain clients, marked or increasing transference issues with certain clients, depression, increase in self-destructive self-soothing behaviors, hypervigilance, feelings of therapeutic impotence or being de-skilled with certain clients, diminished sense of purpose with career, diminished ego functioning (time, identity, volition), decreased functioning in non-professional situations, and loss of hope (Figley, 2002).

Furthermore, for clergy, notes Hart (2003), the essence of the problem is the conflict stuck between expectations and reality. Often, ministers are highly regarded and, countless expectations remain impracticable. "Strongly goal-oriented ministers will almost inevitably experience more frustration than process-oriented ones" (Hart, 2003, par. 4). Additionally, "clergy usually work with volunteers, many of whom aren't there when the work is unrewarding, and they're stuck with each other, since pastors do not hire most of the lay people they work with" (Hart, 2003, par. 4).

In such cases, the worker's general job performance goes down, and mistakes go up. Morale drops and personal relationships are affected; people's home life starts to deteriorate, personality deteriorates and eventually it can lead to overall decline in general health. 


\section{Preventive Measures for Ministry}

With specific focus on the individual and his/her experience with the phenomenon as well as the peculiar work environment, Maslach and Goldberg (1998) suggest that there is usually a relationship between individual and situational factors which may create an impact on the minister. Thus, preventive measures need to be addressed both from an organizational as well as a personal point of view.

The organizational aspects of prevention will remain peculiar to each work environment and administration; however, personal preventive measures may be orchestrated individually. Längle (2003, p. 119) declared that "the importance of relaxation techniques and recreation as a prophylactic is undisputed."

Other authorities studying these phenomena are becoming unanimous in their suggestions to Christian people-helpers (Battiste, 2007; Croucher, 2003), such as the identification of refreshed spiritual disciplines; taking time to rest and relax-Jesus said, "Come apart and rest awhile," and "If you don't rest awhile, you'll soon come apart," adds Hart (2003, Sec. 2, par. 2); seek adequate sleep, as well as exercise and identify socialization opportunities to develop better interpersonal relationships, and a larger support network.

Yet another group of preventive measures for ministry includes time management and ministers' knowledge of the concept of leadership to facilitate the selection of a model that allows for best-practices in pastoral ministry.

\section{Leadership}

The concept of leadership has evolved over time, including the view of leadership as a group of traits or qualities of an individual, the function of a particular individual, or 
even a process which involves some amount of interaction. Greenleaf (2002) suggested that leadership involves the intentional actions of one person who seeks to construct the social world for others. This definition seems to place an enormous amount of 'power' in the hands of the designated leader; thus, on the contrary, another authority, Townley (2009, p. 7), refers to leadership as "a reciprocal process between those who aspire to lead and those who choose to follow on any given task(s)," and also notes that it involves a subtle interplay of many factors which may either be "explicitly stated" or "tacit."

Further, Rost (1993, p. 102) crystallizes this concept in the following definition: "leadership is an influence relationship among leaders and followers who intend real changes that reflect their mutual purposes." He notes that these four elements must be present so that this phenomenon, leadership, can be distinguished from all other forms of human relationships. Leadership is also characterized by various styles and models.

\section{Models of Leadership}

In general, leadership models employed by leaders to mobilize and influence followers (or in some cases, subordinates) include laissez-faire, transactional and transformational leadership. According to one authority, these three components, embrace the full scope of the nature of leadership (Bass and Avolio, 1994).

The model, laissez-faire leadership, is distinguished by more or less an absence of leadership. Since nothing is either transacted or transformed, a "hands-off" and "letthings-happen" approach is evident. Here, no procedures or policies exist, and members of the body are allowed to do whatever they desire; thus, no one attempts to influence anyone else (Hersey, Blanchard, and Johnson, 1996).

Next, the transactional model of leadership is carried out in the context of a 
transaction and is governed by the principle of exchanging one thing for another. According to Burns (2003, p. 23), the best word for this practical, give-and-take leadership was 'transactional'.

In the field of business, this can be seen in the exchange of wages for labor. In essence, transactional leadership seeks to exercise power over subordinates or motivates them by rewards that satisfy their self-interest. Thus, a reinforcement method is utilized towards motivating followers, and this reinforcer may be the equivalent of any consequence that strengthens the action it follows.

Yet another model of leadership is transformational leadership which is of the view that the leader's role is to inspire and empower followers. Burns (2003) describes this as a process of empowerment where followers are motivated and inspired by leaders, and as followers rise above self interests and work toward team goals, they maý serve as leaders as well.

Additionally, transformational leadership embraces four mutually dependent elements-acknowledged as the '4I's'-which, when combined, have an additive outcome that yields the execution of duties beyond normal prospects. This presents a major distinction from transactional leadership (Hall, Johnson, Wysocki \& Kepner, 2002; Kelly, 2003).

The first 'I', idealized influence or charisma, is based on attributes and behaviors that build confidence and trust and provide a role model that followers seek to emulate (Northouse, 2004, p. 11; Simic, 1998, p. 52; Stone, Russell \& Patterson, 2003, p. 3). Such leaders attract a strong sense of identity and are "admired, respected, and trusted" (Bass, Avolio, Jung \& Berson, 2003, p. 208). Therefore, the focal point is the leader in 
person, rather than her/his contextual authority exhibited. Thus, transformational leadership may be performed by any person in an organization in several types of position categories.

Secondly, inspirational leadership sees transformational leaders sending clear messages about mission and purpose. Such leaders present an appealing conception of the future, offer followers the opportunity to see meaning in their work, and challenge them with high standards. Followers are here motivated to serve as all share heightened expectations.

A third ' $I$ ', intellectual stimulation, involves arousing and changing followers' awareness of problems and their capacity to solve those problems (Kelly, 2003). Transformational leaders empower followers by persuading them to propose new and controversial ideas without fear of punishment or ridicule (Stone, Russell \& Patterson, 2003, p. 3). These are the leaders who deem ideas as more significant than processes. Finally, individualized consideration involves developing one-on-one relationships, and demonstrating empathy towards others. Thus, followers are treated individually based on their talents and knowledge with the goal of guiding them in the development of their potentials (Stone, Russell \& Patterson, 2003, p. 3). Kouzes and Posner (2007, p. 16) also noted that the first thing transformational leaders seek to do is to engage in personal values clarification stating, "first the person, then the plan." Thus, this model of leadership transcends material requirements, connecting with individuals as team effort is fostered. 


\section{Other Models}

In the article, Practicing Servant-Leadership, the author noted that, the term servant-leadership was first coined by Greenleaf in a 1970 essay titled 'The Servant as Leader' (Spears, 2004).

Servant leadership is a long term, transformational approach to life and work. It is essentially a way of being that can advance positive changes among others. With followers-rather than the organization-as the focal point, it is not readily implemented and the effects are often seen overtime.

In Patterson (2003, pp. 5, 27) servant leaders are defined as "those leaders who lead an organization by focusing on their followers, such that the followers are the primary concern and the organizational concerns are peripheral." In another definition, the author highlights the perspective of the leader, and notes that

...the servant-leader is servant first ... It begins with the natural feeling that one wants to serve, to serve first. The conscious choice brings one to aspire to lead. That person is sharply different from one who is leader first, perhaps because of the need to assuage an unusual power drive or to acquire material possessions. For such, it will be a later choice to serve-after leadership is established. The leader-first and the servant-first are two extreme types.

Some attributes of servant leaders, as described by Patterson (2003, p. 8) also include the demonstration of agape love. They act with humility, they are altruistic, they are visionary for the followers, they are trusting, they empower followers, and are serving.

For this reason, both servant leadership and transformational leadership encourage collaborative efforts, with servant leadership focusing mainly on service to followers.

Furthermore, Jesus, who lived a life of ministry and service to all, left an example that teaches what it means to serve. Thus, when James and John made their request for 
prominence, He said, "Whosoever will be great among you, let him be your minister; and whosoever will be chief among you, let him be your servant: even as the Son of man came not to be ministered unto, but to minister, and to give His life a ransom for many" (Matt. 20:26-28). In effect, Jesus, was also encouraging team efforts in ministry.

\section{Team Leadership}

\section{Virtual Teams}

According to authorities on this fairly new leadership methodology, virtual teaming emerged as an innovative team process in the 1990s (Furst, Reeves, Rosen, \& Blackburn, 2004).

Virtual teams draw individuals closer together as they represent a variety of disciplines, departments, functions, and geographical locations. Accordingly, wise use of the human resource, as well as various technologies will influence the success of these work environments (Vakola \& Wilson, 2004).

These teams, supported by modern technologies, utilize various electronic means for collaboration. Piccoli and Ives (2003, p. 365) defined virtual teams as "groups of geographically and/or temporally dispersed individuals brought together via information and telecommunication technologies."

Notably, this is a means religious organizations can utilize in an effort to promote cohesion among ministers who serve in distant districts. With the support of information and communication technology, ministers' work structures as well as governing bodies can experience unprecedented levels of flexibility and agility (Powell, Piccoli \& Ives, 2004).

In assessing the benefits of virtual teams, Gibson \& Cohen (2003) submit that 
virtual teams have the potential to contribute substantially to organizational performance and effectiveness. In addition, organizational strategy focused on virtualization may solve problems of competitiveness and improve customer service, employee satisfaction, and efficiency (Klobas \& Jackson, 2008).

Though dismal failure can be the result of the working of virtual teams, research data provides evidence that the benefits of virtual teaming eventually outweigh the drawbacks, allowing organizations to have a faster response time to give them a competitive advantage and provide greater flexibility to individuals working from home or on the road (Robertson, 2006).

\section{Time Management}

Time management refers to the wise use of time towards the accomplishment of goals, projects and tasks (Morgenstern, 2004). The minister needs to function with a flexible mindset, yet this allows him/her to be proactive in planning, prioritizing, organizing, scheduling, setting goals, and delegating responsibilities.

Though ministers generally carry numerous responsibilities, Sanford (1982, p. 17) states that there are times when the minister needs to "decide what is an honest day's work and then go home." This is essential since several researchers have found that burnout is closely related to time management (Mackenzie and Mackenzie, 1995; Feig, 1995), suggesting that there is a significant relationship between how people use their time and their level of stress and burnout.

Another issue in time management relates to timewasters which tend to develop, and they are functional in decreasing the effectiveness and productivity in pastoral ministry. 
Major reasons for wasting time include lack of planning and lack of selfmanagement (Mackenzie and Mackenzie, 1995). Here, lack of planning includes no planning and unrealistic time estimates; therefore, "without it", note Mackenzie and Mackenzie (1995, p. 56), "you are at the mercy of other people's demands on your time".

Next, the lack of self-management includes lack of self-discipline, personal disorganization (Virtue, 1996), procrastination (Josephs, 1992), leaving tasks unfinished, lack of delegation, inability to say "no" (Macy, 1990), and unplanned, excessive socializing (McKinley, 2003).

On the other hand, ministers need to embrace time savers, and the two major means of saving time are improving the ministers' performance in the things which must reflect their expertise and pastoral competency and avoiding the things pastors should not be doing in the first place (Beyersdorf, 1997).

Though the aforementioned may be difficult for the minister to do with consistency, it can be a means of shaping core goals for his/her service with a flexible mindset. In addition to the impact of time management on ministry, Swenson (2004, pp. 119-121) suggests that everyone needs to allocate personal time, family time, sharing time, and God time. Thus, Psalm 31:14-15 states, "you are my God. My times are in your hands" (NIV).

\section{Conclusion}

It can be noted that both burnouts carry effects that reflect upon both the individual's personal and professional lives. A by-product of caring, it is also identified as an indicator that the individual has vulnerabilities that need to be addressed. Furthermore, burnout, though a personal experience with personal effects, is more related 
to the workplace. It is recognized to be job-related strain caused by the place of employment and may possibly have roots in diverse factors. There is still much ongoing research in both concepts, which leaves room for continuous research in the phenomenon. 


\section{CHAPTER 4}

\section{MINISTRY CHALLENGES CONTRIBUTING TO BURNOUT IN THE GUYANA CONFERENCE OF SDA}

\section{The Topography, Regions and Population, and the Economy}

Guyana, once known as British Guyana, is an English speaking Caribbean country located on the northern border of South America (See Appendix A). It is officially referred to as the Co-operative Republic of Guyana, was previously identified as British Guiana, and though located in South America, it is politically and culturally connected with the Caribbean Community. Bordering its eastern, southern, southwestern, western and northern borders are Suriname, Brazil, Brazil, Venezuela, and the Atlantic Ocean respectively (See Appendix A). Being below sea level, it enjoys the ocean breeze of the Atlantic Ocean which is kept from overflowing its banks by sturdy sea walls.

Guyana's 83,000 square miles, according to the two recent censuses, reflect a population as follows: in the year 1991, 723,673; and 2002, 751,223 (Guyana Bureau of Statistics, February 2009). This multicultural population has descriptive statistics as outlined by the statistical agency. Here, "the largest sub-group is that of East Indians comprising 43.5 percent of the population in 2002 . They are followed by persons of African heritage ( 30.2 percent). The third in rank are those of mixed heritage (16.7 percent), while the Amerindians are fourth with 9.2 percent" (Guyana Bureau of 
Statistics, February 2009). Other ethnic groups represented include Caucasians, Portuguese and Chinese.

Furthermore, the citizens of Guyana, irrespective of race, are very religious. This is reflected by the religious composition of the country. There are ten major religions: Anglican, Methodist, Pentecostal, Roman Catholic, Jehovah Witness, Seventh Day Adventist, Bahai, Muslim, Hindu, and Rastafarian. After an examination of the 2002 census, Holder (2007, par. 3 ) notes that according to the 2002 census, a combination of the Christian, Hindu and Moslem communities in Guyana command a membership of over $90 \%$ of the population.

This population of Guyana is scattered among its ten regions, with the largest faction residing in the Demerara region, commonly referred to as region 4. The recent census highlighted that region 4, where Georgetown, the capital city, is located, carries some 40 percent of the country's population. This density was compared with the combination of regions 6 and 3 that together total another 30 percent of the population. Despite the populace noted in those three regions, Guyana comprises a total number of ten regions which are as follows: Barima Waini, Pomeroon-Supenaam, Essequibo Islands-West Demerara, Demerara-Mahaica, Mahaica-Berbice, East Berbice-Corentyne, Cuyuni-Mazaruni, Potara-Siparuni, Upper Takutu-Upper Essequibo, and Upper Demerara-Berbice. These regions stretch across the country's 83,000 square miles, and while some are accessible by land, others are solely accessible by rivers.

Guyana has many rivers. Nonetheless, the three major waterways are the Essequibo, the Demerara, and the Berbice rivers. There is also the Corentyne river which borders with Suriname. It must be noted that these rivers are miles in length and width, 
thus they must be crossed by boats, while others can also be traversed by the country's floating bridges (Berbice or Demerara bridges).

\section{Guyana Affected By Migration}

Whereas the last three censuses recorded slight increases in the population, many Guyanese continue to migrate to other countries. One of the many reasons Guyanese migrate to other shores is the economical condition of the country. Guyana's economy suffered over the years dating back to its independence in 1966. Then president Forbes Burnham propagated socialist ideas that the country could exist independently of other nations. Thus, noted A. Joseph (personal communication, September 10,2007), they sought to take control of all economic activity by nationalizing foreign-owned businesses, an isolation that has cost the country's economy dearly.

History bears witness of the struggles the working class had, and in many cases, still has to survive. The minimum wage in the 1990's made it almost impossible to survive and still poses a challenge to a family's existence. According to the Country Studies Program (par. 2), "conditions were harsh for the roughly 764,000 people living in the country. In 1990, an estimated 40 percent of workers earned the minimum wage, equivalent to only US\$0.5 per day. Three factors-the flourishing illegal economy, the cash remittances that Guyanese citizens received from relatives living abroad, and the country's near self-sufficiency in food production—were all that kept the economic decline from becoming a disaster."

While it is true that the economy has improved over the years as compared to the 1980s and 1990s, there is still much to be desired. At the death of President Forbes Burnham, his successor, President Hugh Desmond Hoyte, went about an economy 
recovery process. He sought to have the international debt written off and encouraged foreign investment (A. Joseph personal communication, January 12, 2008).

Regardless of the effort to rebuild Guyana's economy, many Guyanese continue to migrate to other countries, mainly North America, to seek a better standard of living. Migration has become fashionable in this country. One authority noted that Guyana has exhibited a migration culture for some thirty years and that many individuals and families are waiting patiently at the visa traffic light for the green signal to travel to North America (Misir, 2008).

By the same token, many islands of the Caribbean suffer from the migration of significant numbers of professionals. "Approximately $30 \%$ of the labor forces of many islands have left, and more than $80 \%$ of college graduates from Suriname, Haiti, Grenada, and Guyana have emigrated, mostly to the United States" (Palmer, 1990).

Guyana certainly is a victim of brain drain. Wilkinson (1999), in speaking of the migration problems faced by Guyanese, noted that large numbers of frustrated teachers are migrating and are currently earning up to four times what they earned in Guyana.

Accordingly, the Seventh-day Adventist church, during the years of this paper's focus - 1995 to 2007 - was also affected by the problem of migration. While the church and its membership grew during these years, it experienced some setbacks as a result of the migration of many of its ordained ministers to countries where the economy was more favorable for an improved standard of living, opportunities for children, and change in work environment. 


\section{Brief History of the Growth and Leadership of the SDA Church in Guyana}

The history of the Seventh-day Adventist church in Guyana dates back to the 1800s. Common knowledge among members is that the Advent message reached the shores of Guyana through a roll of Biblical handouts delivered by a sea captain. Ian Green (1991, par. 1) states,

although the beginning of Seventh-day Adventism in Guyana has been traced to a roll of religious papers reluctantly carried by a sea-captain in 1883 on the request of W.J. Boynton of the International Tract and Missionary Society (ITMS) office in New York City, the earliest specific reference to SDA work in Guyana indicates that SDA teachings first found its way to Guyana through Joseph Brathwaite.

Joseph Braithwaite directed his energies in the area of literature evangelism and led many to Christ. Further, there were over twenty individuals reportedly observing the Sabbath truth when ministerial help was requested in 1885 (Green, 1991).

The subsequent spreading and incessant growth of the advent message got the attention of the SDA headquarters, the General Conference, in the USA. This led to their sending missionaries and colporteurs to assist in the work in this part of the vineyard. Of significance was the contribution of Elder G. G. Rupert who was instrumental both in spreading of the message through the colporteur ministry and in organizing the first major church, Central SDA, as well as, a Sabbath school department. Green (1991, par.

5) states,

At the General Conference session held in Battle Creek, Michigan in November 1886, a decision was taken to send Elder G. G. Rupert to Guyana. He left New York on January 18, 1887 accompanied by George King, the pioneer SDA canvasser. They arrived in Georgetown at the end of the month and through their efforts some $\$ 500.00$ worth of books and periodicals were sold and a church and Sabbath School organized. While in Guyana Rupert baptized thirty persons and the Sabbath School was organized with a membership of forty.

The next major leg of the early work was performed by the first resident minister, 
Warren G. Kneeland and his wife, who arrived in Guyana in 1893. Prior to this appointment, the church group was instable, thus some immediate moving out was noted when the minister established the second church in an area called Bootooba. Due to the presence of the church in this location, Indian tribes (Amerindians) gained access to the message which soon led to carrying the message to the Essequibo region (C. Lowe, personal conversation, March 20, 2005).

At that time, this work among the Amerindians was the highlight of the Advent work in Guyana. Elder Ovid E. Davis, an American missionary, also played a major role in the spreading of the message among this tribe. In support, Chilson (1991, para. 3) states,

In 1910 two Indians from an isolated Mount Roraima tribe came to the Adventist office to appeal for a missionary. Finally, a year later Davis resolved to make the hazardous journey in company with an Indian guide. Canoeing up dangerous rivers, following tortuous jungle trails, and greatly weakened by fever, he reached the tribe from which the request came. As best he could, he presented to them the gospel story, also teaching them several songs and the English alphabet.

Davis' contribution set the foundation for Adventism among the Amerindians. In ensuring that the work was successful among this tribe, He lived and worked tirelessly among them. On account of his missionary labors, he witnessed the baptism of over 300 Amerindians, and built three churches (Green, 1991).

\section{Guyana as a Mission}

Over time, the Seventh-day Adventist church in Guyana grew to be a part of the body of churches in the East Caribbean Conference with headquarters located in Trinidad and Tobago. In 1945, Guyana had acquired mission status with three major pastoral districts of Georgetown, Essequibo and Berbice (Conference Statistical Report, 1957). 
Accordingly, the first president of the Guyana Mission was named—Judson B. Beckner. Having served with distinction, Beckner was succeeded by the following presidents respectively: L. A. Arthur; E. J. Parchment; M. E. Neblett; and V. T. Boyce. Finally, the mission period came to an end with a total membership of 11,003 members (Conference Statistical Report, 1957).

\section{Guyana as a Conference}

Naturally, with the growth of membership and other advances, the Guyana mission acquired Conference status on January 13, 1976. Here, Roy I. McGarrell, the first conference president, served a total of 11,003 members.

Due to the brevity of this paper, the focus will remain on the numerical growth of members and ordained ministers for the period 1997-2006. This period recorded a continuous increase in membership —an average of one thousand seven hundred members per year. The membership of over 50,000 was spread throughout several churches and pastoral districts. The Conference Statistical Report states, "The Guyana Conference of Seventh-day Adventists has a membership of over 50,000 distributed in 23 pastoral districts with approximately 187 congregations scattered in all 10 regions of the country." Unfortunately, this growing membership was supported by a fluctuating total number of ministers over the same period (See Appendix B, Tables 1 and 2).

Furthermore, the conference's statistical statement reported that a total number of fourteen ministers left fulltime ministry and sought employment-most of them overseas. Of the fourteen ministers leaving the ministry, eight of them were ordained, while the remaining six were licensed ministers (See Appendix B, Table 3). 


\section{The Duties and Work Load of the Minister}

The many responsibilities borne by the Adventist clergy, in tandem with numerous expectations, set the stage for overload and overwork in ministry. When one accepts the call to ministry, it is clear that with ministry come certain basic responsibilities. However, the limited human resources in the form of the clergy result in the enormity of the task that creates an environment susceptible to burnout and compassion fatigue.

On the other hand, ministers in Guyana require only the basic training from a Bachelor of Arts Degree in Theology to qualify for service. It is evident though, that the demands of ministry reach far beyond the initial spiritual preparedness gained from an undergrad program. Thus, it must be noted that the church is not only a "hospital" for spiritual sickness, but also a place of refuge for people with societal problems and psychological, social, mental, and physical issues. Even more disturbing is the reality that each minister has to serve multiple congregations, having to address large numbers of issues in each aforementioned category.

During the years 1997-2006, pastoral districts ranged from five churches to as many as twenty-three churches. Thus, each pastor in the Guyana Conference was given the responsibility of shepherding many churches simultaneously, rendering adequate pastoral care and effective management. In addition, conference administrators expect pastors to perform their duties as laid out by the minister's manual, as well as be effective soul winners in evangelistic campaigns and achieve other General Conference goals set by the administrators themselves.

This reinforces the fact that the minister seldom experiences a sense of 
'completion' in his duties; instead, the ministry entails a continuous blitz of demanding activities, and programs. Consequently, in many cases, the evidence of results is overshadowed with ambiguity and can lead to the minister's stretching himself out very thinly, leaving several hanging ends'and feelings of exhaustion. This uncertain, unaccomplished feeling, attributable to demanding work with minimal results can lead to compassion fatigue and burnout.

By the same token, the clergy's energy becomes depleted, also as a result of striving to meet others' expectations. Conference administrators assign ministers to districts based on their assessment of needs. Thus, the administrators have their own expectations; each district has its peculiarities, problems and needs, so as a body, it comes with its own expectations; each church within the district also embraces its own unique culture, problems and needs that shape its expectations of the minister; furthermore, each individual member within each congregation presents his/her personal expectations.

These expectations can influence the leadership style and work attitude of the minister. The fact cannot be ignored that it is unrealistic for any human being to possess all the gifts and qualities necessary to satisfy the numerous diverse expectations of the profession adequately. With the spotlight on the minister's achievement and style, some ministers become goal-oriented. Thus, they focus more on administrative work, setting and achieving goals at all costs. This approach may, at times, prove dangerous to the minister's health and social relationships.

Although the minister may attempt to meet everyone's expectations, s/he cannot. As a result s/he is ridiculed, criticized, and in many cases, becomes the 'enemy' of some. 
These behaviors by members cause the minister to exert energy to please others, as well as mend relationships. Therefore, the depiction of such a minister is one working feverishly to achieve church and administrative goals, attend to the spiritual and physical needs of the church, and at the same time, work towards mending the divisions in his congregations. The truth is that such a minister is on the path of becoming physically drained and mentally exhausted.

One of the most troubling assumptions in ministry is the belief that the minister is immune to problems and issues. While the members have the minister to go to and vent their grief, pains, trauma and suffering, most ministers lack that level of relationship where their personal issues are tackled and resolved.

Additionally, the nature of the ministry may at times trigger an isolation mode for the minister. S/he is expected not to have problems, not to have the need to vent feelings or mental anguish, and for many, it is forgotten that $\mathrm{s} / \mathrm{he}$ is human. The minister is left alone to bear personal psychological and emotional trauma, as well as that which stems from the issues of others.

In contrast, counselors in the world of work have confidential professional colleagues - counselors - with whom they may review cases and vent after attending to the trauma of clients. In ministry, the minister, who performs the same duties of the worldly counselors, has no system in place for venting. The minister, therefore, is likely to suffer from the compassion fatigue form of burnout as well.

\section{A Brief Summary of Burnout Experiences}

Over the first few years of my ministry experience, five of my pastoral mentors shared their experiences in an effort to advise me against overwork. Four of these 
ministers reside overseas and one recently returned to ministry in the Guyana Conference. Their stories revealed evidence of overwork and burnout.

One served the Guyana Conference as a minister and youth director for many years prior to his family's migration. As a district pastor, he worked without a car while serving churches that were a large number of miles apart. These districts comprised as many as eight to twelve churches. He was later elected to serve the entire country as the youth director.

While he enjoyed the ministry, he told of the effects it had on his health. His physical health was affected. He noted that he started to experience difficulties sleeping and lack of energy to perform effectively as a result of the many years of conitinuous service without sabbaticals. This, he said, drove him to leave the shores of Guyana and seek employment elsewhere.

Another colleague and mentor who served many years as an administrator in this very conference conveyed his experience of burnout to me. He told of his labors in public evangelism and of raising up numerous churches, along with his 'everyday' pastoral duties. He pastored large districts while performing the duties of evangelist. $\mathrm{He}$ recalled that after conducting an evangelistic campaign one year, he became ill and visited his physician. He was subsequently told by his physician that his illness was a direct result of overwork, and if he did not take an immediate sabbatical, physical and mental break downs would be his lot. As a result, he left the ministry in Guyana and served in other fields for approximately ten years, after which, he returned and served effectively as a conference administrator.

Yet another two of my colleagues who are presently shepherding churches in 
other fields told of their ministry experience in Guyana where they both served for over ten years. Both of them told of how they had become bitter individuals. They had started to be easily angered and complaining was growing to be a habit. They felt as though they had become useless and no longer felt called to the ministry. They had stop attending church board meetings regularly, and spent most of their days at home. The bottom line is that they were burned out. They accepted calls to other fields where they are currently pastoring fewer congregations and are enjoying the ministry.

One minister who is presently unemployed also conveyed to me why he took his family and left the ministry after serving the Guyana conference for over fifteen years. He had become burned out. His family's financial needs could not be met due to his inadequate salary. Over time, he grew frustrated, became physically exhausted, and mentally tired due to consistent overwork. His congregations began to cómplain of his ineffectiveness and continued absenteeism. He came to a point where he felt he needed a break from the ministry in Guyana. Thus, he migrated.

All five of these ministers had one thing in common-they became burnt-out. Their unanimous claim was that they were overworked and became physically and mentally drained. Thus, they needed to remove themselves from the ministry in Guyana.

\section{A Typical Day of the Minister-A Link to Causative Factors for Burnout}

I was privileged to serve as a minister in this part of the vineyard (Guyana Conference). I began as an intern in the New Amsterdam District, under the supervision of a senior minister, Pastor Hubert Jack. We were the pastors for eleven churches. Two of the churches were only accessible by water (sea and river) and took five and nine 
hours respectively to get to those locations. Whenever we visited these two churches, we stayed between three to seven days to fulfill our pastoral duties since these churches were visited once per quarter.

Still, we did our best to ensure that each church received adequate and equal attention. We tried to attend every leadership meeting and as many church programs as possible. Evangelism was promoted as the main reason the church exists. Thus, Pastor Jack and I led from the front. One year, I served as the evangelist for two five-week evangelistic campaigns. While conducting these meetings and preaching nightly, I was still expected to fulfill my other pastoral duties such as visiting members, conducting meetings, funerals, weddings, etc.

Upon leaving New Amsterdam, I soon became the senior pastor of the West Demerara/Essequibo district. There, I was given the responsibility shepherding fourteen churches where three of these congregations were only accessible by sea. In an effort to minister to these congregations, I preached at two churches on many Sabbaths. This was done by specially rearranging the services to avoid program clashes.

In order to equip the leaders to serve, I conducted ongoing training programs and also sought to be an example. In addition to chairing church board meetings as often as possible, I sought to attend various departmental meetings. Visitation was also very important, since the administration expected ministers to visit each of their members before the calendar year ended. Apart from these duties, I served as the evangelist for two four-week Bible Series each year.

After three years as the district pastor for the Demerara/Essequibo district, I served as the pastor of five churches. While this was a relatively small district compared 
with others, it nonetheless demanded much attention and effort.

Accordingly, the typical day of a minister in the Guyana Conference entails much time in pastoral counseling, along with the aforementioned meetings, and home and hospital visits. It is not the norm here for church members, or any member of the public, to acquire counseling services through payment. Thus, it is not customary to locate private counseling practices easily in the society. Bearing in mind that Guyana is a very religious society, it is the custom for citizens, whether members of a minister's congregation or not, to seek advice and counsel from religious leaders. Hence, most ministers perform different forms of counseling, and these services focus primarily on premarital, mental health, grief, and psychological counseling.

Of concern is the fact that a large number of ministers are neither trained nor equipped to perform these counseling services. Yet on a regular basis, they are called upon to counsel people with terminal illness, domestic violence issues, those addicted to various drugs, those who have suffered the loss of loved ones, and so forth. In conversation with many colleagues, it became evident that we all were tired and fatigued on account of work overload, as well as the nature of our'services.

Added to the nature of the services is the fact that the minister works with the same people over an extended period. Thus, unlike the counselor who can discharge or readily refer clients to another professional, the pastor can be "stuck" with the same members and their problems for years. Though physical energy is seldom required when addressing members' needs, there is a constant demand on the minister emotionally, mentally and spiritually. 


\section{Indicators of Burnout}

In dialogue with my colleagues at ministerial meetings, and other personal encounters, the concern has always been that we are overworked and in need of sabbaticals or vacations. Accordingly, I have seen many ministers petitioning often to absent themselves from church services and other meetings. Others discontinue the fulfillment of other duties such as visitation and even pastoral counseling; their cry highlighted the physical and mental fatigue encountered in their ministry.

I have also witnessed the experience of four colleagues as they walked away from the ministry in Guyana.. Of the four, two of them migrated to overseas fields, citing the need for a change from such rigorous service, while the other too laterally embarked upon career changes. On the other hand, several ministers who, because of circumstance, cannot seek a change in career or migrate to other fields are lethargic in their ministry, and their service may appear to be half-hearted.

In fact, I can recall many pastors' meetings where administrators pleaded with ministers against working under "false pretence." Those words were uttered by the administration because of the numerous complaints by members about the lack of service from their pastors. Some districts even requested the administration to change their pastor for one who will offer them more service.

Accordingly, various ministers display the following signs: forgetfulness, short temper/impatience, obesity, anger, sleepiness and insomnia, tardiness, unprepared sermons, frequent reminiscing on the problems faced by members, seemingly busy but accomplishing little, feelings of ineffectiveness and questioning their calling, difficulty relaxing, guilt-ridden when deciding to take a vacation or day off, feeling tired, 
dreams/flashbacks of cases being counseled.

\section{Conclusion}

The magnitude of the pastor's work in the Guyana Conference of Seventh-day Adventist has proven to be very demanding and excessive for ministers in this part of the vineyard. Such labor, such exhausting efforts-physical, emotional, mental as well as spiritual has and/or will continue to be a causative factor for burnout.

Therefore, the well-meaning minister who keeps striving to meet the needs of his or her members without taking time to address personal needs for respite and sustenance of body, soul and mind, can be on the path to personal and professional demise.

For this reason, discussions about cure and prevention from both an individual and organizational point of view are needed to curb this trend. The following chapter will address the identification of strategies geared towards mitigation of the problems or potential problems of burnout among ministers. 


\title{
CHAPTER 5
}

\section{SEMINAR PRESENTATIONS}

\section{Effects and Impacts on the Pastor's Well-being, Implications for Pastoral Leadership, Prevention of Burnout}

Seminar Presentations Outline

\author{
Presentation 1: Signs and Symptoms of Burnout \\ Presentation 2: Connecting Leadẹrship Style and Burnout \\ Presentation 3: Impact on Pastoral Ministry
}

Presentation 4: Strategies for Avoiding Burnout in Pastoral Leadership

Presentation 5: Preventing Burnout through Enrichment of Spiritual Disciplines

Presentation 6: Congregational Role in Preventing and Managing Burnout in Ministry

\section{Presentation 1: Overview and Signs/Symptoms of Burnout}

Introduction

Clergy are unique in that they are among the only professions from whom people seek help for a wide repertoire of needs and problems. For example, in the US, four out of ten people who experience mental health problems first seek assistance from the clergy instead of from psychologists, psychiatrists, social workers, or counselors (Weaver et al., 1997; Weaver et al., 2001).

The demands on the clergy can exact a toll on their holistic health. Lehr (2006, p. 3) suggests that many pastors are experiencing pain in ministry. All of these ministers 
are desirous of learning how "to serve faithfully without losing their minds, their families, and even their souls."

\section{Content of Presentation 1}

Devotional. "Beloved, I wish above all things that thou mayest prosper and be in health, even as thy soul prospereth" (3 John 1:2, KJV).

Signs and symptoms of burnout. Overview of burnout. General signs and symptoms. Burnout signs and symptoms.

Activity break. Create a handout of the list of signs and symptoms. (a) Is this applicable to me? Ask participants to individually place a tick next to those with which they identify. (b) PAIR and SHARE: Request that the participants pair off and then share personal experiences with any signs or symptoms (or discuss the experience of another known clergy with whom they can identify).

It is significant to note that a recently conducted national survey (2001) of 2,500 religious leaders by Duke Divinity School found that $40 \%$ percent of ministers are depressed and worn out (Wells, 2002).

Staton et al. (2007, p. 356), defines burnout as a "psychobiological phenomenon in which systems may occur suddenly and persist over long periods of times." The authors highlight three stages of burnout: "Stage one is Enthusiasm." In this stage workers enter the job with "unrealistic expectations regarding the outcome;" Stage two is "stagnation." In this stage "personal, financial, or career needs are not being met." In addition, personal effort is not met with sufficient results. Stage three is "frustration." In this stage, the worker begins questioning his or her effectiveness on the job. Thus, the feeling of incompetence is experienced, and moves to stage four, "apathy." In this stage, 
"the worker is in a state of disequilibrium and immobility."

Figley (1995), describes compassion fatigue as a state of tension and preoccupation with the individual or cumulative trauma of clients as manifested in one or more ways: re-experiencing the traumatic events, avoidance/numbing of reminders of the traumatic event, all combined with the added effects of cumulative stress (burnout).

\section{Signs and Symptoms of Burnout}

The effects of burnout, as was noted before, can express themselves in seven key areas in the human experience. These are cognitive (thinking), emotional (feeling), behavioral (actions), spiritual (relationship to God, self and others), personal relations, somatic (physical), and work performance (competency). These effects express themselves differently for various individuals. The following are examples of symptoms:

Cognitive: the victim may portray lower concentration and self-esteem, rigidity, and may even contemplate harming him/herself.

Emotional: the victim may feel powerless, guilty, depressed, overly sensitive, and depleted.

Behavioral: the victim may become irritable, withdrawn, moody, and experience sleep disturbance.

Spiritually: the victim may begin to question the purpose/meaning of life, become angry with God, lose faith in God, and may even question personal religious beliefs.

Personal Relations: the victim may become withdrawn; experience decreased sexual interest, loneliness, and frequent interpersonal conflicts.

Somatic: the victim may experience sweating, rapid heartbeat, breathing difficulties, and dizziness (Figley, 2002). 
Work performance: the victim may experience low morale, low motivation, negativity, staff conflicts, and absenteeism (Figley, 2002).

Other symptoms which may be manifested both in burnout and compassion fatigue cases, but which are more common with the compassion fatigue form of burnout cases as noted by Figley (2002) include

Increased negative arousal; intrusive thoughts/images of another's critical experiences; difficulty separating work from personal life; lower frustration tolerance; increased outbursts of anger or rage; dread of working with certain individuals; marked or increasing transference/counter transference issues with certain individuals; depression; ineffective and/or self-destructive self-soothing behaviors; hypervigilance; decreased feelings of work competence; diminished sense of purpose/enjoyment with career; lowered functioning in nonprofessional situations; and loss of hope.

Similarly, Neils (2008, par. 7) has also identified some signs and symptoms which are more closely related to the incidence of burnout. These include

Chronic fatigue - exhaustion, tiredness, a sense of being physically run down; anger at those making demands; self-criticism for putting up with the demands; cynicism; negativity, and irritability; a sense of being besieged; exploding easily at seemingly inconsequential things; frequent headaches and gastrointestinal disturbances; weight loss or gain; sleeplessness and depression; shortness of breath; suspiciousness; and feelings of helplessness.

\title{
Presentation 2: Connecting Leadership Style and Burnout
}

\author{
Introduction
}

Ministers need to have a clear understanding of their role in the local congregation: whether they are managers or leaders. Such an understanding will determine the manner and approach the minister pursues to implement plans and achieve goals. As a result of the number of congregations allotted to one minister in the Guyana Conference, the world view of the average minister is that he is a manager assigned with management responsibilities. It is therefore necessary, in an attempt to avoid burnout, to 
understand the difference between leadership and management in the context of a group or team of individuals of which the minister is a part.

\section{Content of Presentation 2}

Devotional. "After that he poureth water into a basin, and began to wash the disciples' feet, and to wipe [them] with the towel wherewith he was girded. ... So after he had washed their feet, and had taken his garments, and was set down again, he said unto them, 'Know ye what I have done to you? Ye call me Master and Lord: and ye say well; for [so] I am. If I then, your Lord and Master, have washed your feet; ye also ought to wash one another's feet. For I have given you an example, that ye should do as I have done to you. Verily, verily, I say unto you, The servant is not greater than his lord; neither he that is sent greater than he that sent him. If ye know these things, happy are ye if ye do them'"'(John 13:1-17, KJV). Key Points: Jesus washed the disciples' feet; Jesus was both a leader and a servant.

Connecting leadership style and burnout. A minister's worldview of leadership contributes to burnout/compassion fatigue. Differentiating between management and leadership.

Activity break. Open discussion: Advantages and disadvantages of management and leadership within the Guyana context.

Connecting leadership style and burnout. Jesus' model of servant leadership is the minister's example.

Closing activity. SQUARE \& SHARE. Request that participants divide into groups of four. Participants/ministers review their leadership styles and list/identify avenues toward achievement of servant leadership. 
Management and leadership are different styles in supervision within a team. They stand on opposite sides in the field of supervision. Rost (1993, p. 102) states that leadership "is an influence relationship among leaders and followers who intend real changes that reflect their mutual purposes."

Therefore, it can be inferred that leadership is not individualistic, but inclusive, and focuses on fostering team based environments. Kumle and Kelly (2006, p. 12) states, "Leadership does not provide the direction to a well-oiled team. Leadership instead provides the vision of the end result. The total team must provide the path and direction of how to get there."

With its focus on teamwork, leadership seeks to create an environment of empowerment and trust. According to Kumle and Kelly (2006, p. 12), such a leadership environment contains the following characteristics:

1. "Leadership operates in a trust-based environment." 2. "People are important and come first before things, goals and visions." 3. "Open and honest forms of communication are standard practice." 4. "No secrets or hidden agendas are present within the organization. Vision for the end product is present, not the rule or paths to get there."

On the other hand, management is further defined by Rost (1993, p. 145) as "an authority relationship between at least one manager and one subordinate who coordinate their activities to produce and sell particular goods and/or services." Unlike leadership, where there are leaders and followers and an influence relationship, in management, there are managers and subordinates and an authority relationship wherein managers have control and can give directives either non-coercively or coercively (Rost, 1993). 


\section{Advantages and Disadvantages of Management and Leadership within the Guyana Context}

Although the results of management may carry a glorified appearance of success, ministers, in their quest to be like Jesus, should certainly seek to adopt the approach of leadership over management. Leadership creates an environment where each member of the team feels valued, trusted, and bears equal responsibility according to their spiritual gift to achieve the shared vision and goals. There is also transparency and honesty in the process, coupled with the principle that people and relationships are more important than goals.

In reality, ministry in Guyana is mainly performed based on the Moses model of supervision. This model boasts a pyramidal structure which has been employed over many decades by various institutions and holds the top person in the hierarchy as responsible for the successes or failures of the organization (Greenleaf, 2002). This hierarchical system holds the head as the chief.

Accordingly, such an individual is viewed as the boss who gives instructions, sets goals and visions and passes them down to subordinates. After all, the premise of the "chief's way or the highway" is the functional foundation of this model. Greenleaf (2002, p. 74) attests, "the natural reaction to a call for stronger leadership is to try to strengthen the control of the one person at the top." This model has more management than leadership characteristics.

In contrast to the Moses model of leadership is the "primus model." This model, which has its roots in Roman culture, seeks to distribute leadership among team members. Greenleaf $(2002$, p. 74$)$ notes that "it is the form where the principal leader is primus inter pares - first among equals. There is still a first', a leader, but that leader is 
not the chief." This model advocates team work among equals. Thus, it is appropriate to state that it presents more of the characteristics of leadership rather than management.

Furthermore, the leadership example of Jesus, whom we are to have as our model, is one of servant leadership. Sendjaya and Sarros (2002) suggest that service comes first for servant leaders, while leadership is born out of the signposts for development noted in the tenure of the aforementioned experience. Here, the transition to leadership does not readily alter the service-oriented heart; however, a movement from first being a leader toward service may prove to be a challenge for many.

In fact, Jesus' model of leadership is one of servant leadership where the servant leader is neither chief nor boss, but a servant. The foundation of this model is in empowering others and team ministry. Jesus empowered the disciples to be coworkers with him. Thus He was willing to make available to his team the same power and authority that he possessed. For this reason, he could have been "physically absent," yet the team was still capable of advancement, embracing its shared vision toward the realization of goals. The Bible notes that he empowered disciples: "And he called unto him the twelve, and began to send them forth by two and two; and gave them power over unclean spirits" (Mark 6:7 KJV).

As a servant leader, Jesus did three main things for his team of disciples: he called them; empowered them; and sent them. In calling them, he taught them. Matthew Henry Commentary (Notes: mark 6:7) states, "Hitherto they had been conversant with Christ, and had sat at his feet, had heard his doctrine .... and now he determines to make some use of them; they had received, that they might give, had learned, that they might teach. ... Jesus hid nothing from them rather, He imparted to them all he had for the 
fulfillment of his Father's will."

On the whole, ministers must be cognizant of the fact that their adopted leadership style in ministry can contribute to burnout. Should the minister operate as manager or boss, thus failing to foster an atmosphere of team ministry-where people are empowered and allowed to take control of the process toward a shared goal, such a minister is a prospect for burnout.

Maslach (1982, p. 38) highlighted in her writings that there are a variety of job settings where one common burnout trigger is evident, that is, work overload. "Whether it be emotional or physical, the burden that exceeds the person's ability to handle it is the epitome of what we mean by stress."

After analyzing the concepts of leadership and management, it can be concluded that one of the major means that ministers may employ in managing the phenomena of burnout is the style of servant leadership. They must first see themselves as servants of God and the people instead of chiefs or lords. For this reason, the apostle declared, "Feed the flock of God which is among you, . .; not for filthy lucre, but of a ready mind;

Neither as being lords over God's heritage, but being ensamples to the flock" (1 Pet 5:2-3, KJV).

However, being a servant to the people does not entail doing the work for them, but facilitating the process of development to their full capacity. Such ministers seek to create an atmosphere of team ministry where there are shared goals and visions, empowerment, mentoring, freedom of expression, and opportunity for the utilization and development of individual gifts. 


\section{Presentation 3: Impact on Pastoral Ministry}

\section{Introduction}

The minister's responsibility is to take care of the flock entrusted to his/her care.

Hence, as Jesus was about to leave his earthly flock, he commissioned the apostle Peter, “... Simon, son of Jonas, lovest thou me? He saith unto him, Yea, Lord; thou knowest that I love thee. He saith unto him, Feed my sheep" (John 21:16, KJV).

Like the apostle Peter, Jesus' undershepherd, pastors are also current undershepherds with the responsibility of feeding and caring for God's flock. Therefore, the work of the minister is to feed the flock through the spoken word and to work personally with individual sheep in the work of caring for them. It is pertinent to the success of service that the minister maintain a healthy, spiritual relationship with the Lord, as well as a vigorous social and spiritual relationship with the members. Croucher (2003) notes that burnout, which is emotional overtiredness, makes the minister unable to have a healthy relationship with both the Lord and the flock entrusted to his/her care.

\section{Content of Presentation 3}

Devotional. "And Ahab told Jezebel all that Elijah had done, and withal how he had slain all the prophets with the sword. Then Jezebel sent a messenger unto Elijah, saying, So let the gods do [to me], and more also, if I make not thy life as the life of one of them by tomorrow about this time. And when he saw [that], he arose, and went for his life, and came to Beersheba, which [belongeth] to Judah, and left his servant there. But he himself went a day's journey into the wilderness, and came and sat down under a juniper tree: and he requested for himself that he might die; and said, It is enough; now, O LORD, take away my life; for I [am] not better than my fathers" (1 Kings 19:1-4, 
KJV). (Key Point: Commitment to service wavers under exhaustion.

Impact on pastoral ministry. Prayer and Bible study hindered. Preaching and teaching affected. Interpersonal relationships avoided.

Activity break. Testimonies (pre-arranged). Personal struggles and victories. Open discussion.

Prayer clusters. Divide into groups of three or four. Sharing prayer requests. Three or four short prayers for cluster members.

To be a victim of burnout is to be exhausted to the extent that one's holistic functioning is affected. As has been noted, mental, emotional and physical exhaustion and a resulting general negative outlook on life complicates the day to day functioning of the wounded helper.

When one is exhausted to this point, it is very difficult to be spiritually effective since quality time for prayer and Bible study is encumbered. In effect, the minister starved of prayer and study of God's Word grows empty spiritually, seeks to live on past blessings and experiences with God, and may even resort to serving up stale food or leftovers to the flock. After all, one can best share from that which is had; thus, if the minister is empty spiritually, then he cannot fulfill effectively his responsibility of feeding the flock spiritually. E. White (1923, p. 507) reinforces this point as she stated, "a good work cannot be done by the human agent alone. ... there must be, a vital connection with God.... Then with the soul all aglow with zeal for the Master, we can be a blessing to others".

Furthermore, preaching and teaching the Word requires the minister to be a student of the word. S/he must water his own soul with the Word to be best fitted to bless 
others with his inspirations and revelation from the Word. It is thus written, "Whosoever drinketh of the water that I shall give him shall never thirst; but the water that I shall give him shall be in him a well of water springing up into everlasting life" (John 4:14, KJV). Naturally, like a newborn babe with a working 'knowledge of sucking', partakers of the Word are equipped to guide others to the treasures stored therein. The Bible also says, "he that watereth shall be watered also himself". (Prov 11:25). Thus, ministers who are burned out are in danger of not fulfilling their duties of feeding the flock since their exhaustion can be a hindrance to their communion with God and study of His word.

In additional, burnout/compassion fatigue affects the minister's relationship with others. The minister is entrusted with the responsibility of attending to the individual needs of members. For this reason, s/he needs to possess some interpersonal skills to function best in a capacity of admonishing, counseling and encouraging members. Archibald Hart (Croucher, 2003, Sec. 4, par. 2) identifies some symptoms of these phenomena as "demoralization" (belief that one is no longer successful as a pastor), "depersonalization" (treating oneself and others impersonally), "detachment" (withdrawal from active functioning), "distancing" (evading social and interpersonal contacts), and "defeatism" (a feeling of being crushed). When ministers are at this point in their ministry, they are unable to fulfill their duty to members through one-on-one contact or other means of interaction.

At risk, also, is the minister's sense of satisfaction in service, and when the minister no longer has a sense of job satisfaction, like in any other service or vocation, he can become depressed. As was noted in the prior section, depression is one of the signs of burnout/compassion fatigue. Zunker (2006, p. 19) notes that "depression can both 
lower work performance and affect non work factors." The minister's work performance can be affected holistically.

\section{Presentation 4: Strategies for Avoiding Burnout in Pastoral Leadership}

Introduction

Ministers are prospects of burnout as a result of the "never ending" nature of the service they provide. Unlike other professions that require workers to perform duties over a daily assigned time period (after which, personal time can be realized), the minister's duties lack fixed work hours. The minister is either on active duty or on call twenty four hours daily, and seven days a week. When s/he is not chairing a meeting, attending to the needs of a member, preaching, conducting other services or visiting, $\mathrm{s} / \mathrm{he}$ is equipping her/himself through study to feed the flock.

This never-ending nature of ministry utilizes the minister's spiritual, mental and physical energy continuously. Thus, unless the minister manages her/his energy and time wisely, s/he can become a victim of burnout-compromising the ability to serve effectively.

\section{Content of Presentation 4}

Devotional. "And when he had sent the multitudes away, he went up into a mountain apart to pray: and when the evening was come, he was there alone (Matthew 14:23, KJV):" Key Point: Jesus did not work endlessly.

Strategies for avoiding burnout in pastoral leadership. Energy preservation. Team ministry.

Activity break. Make double or triple copies of the 8 suggestions for effective 
team play (according to size of audience). Cut out each, crumble and shuffle all together in one bag. PAIR. Request that audience be divided into pairs. Each pair will draw 1 suggestion from the bag. Each pair will discuss the significance of the chosen suggestion to their ministry as team players. SQUARE. Each pair will identify another pair who discussed the same suggestion. Share differences and similarities from paired discussions. SHARE. Facilitator will randomly draw feedback from various squared groups.

Strategies for avoiding burnout in pastoral leadership. Energy Preservation. Gift-based ministry. Team ministry. Taking a day off. Vacation time-have fun. Others' expectations.

\section{Energy Preservation}

There are three major ways by which energy conservation in ministry can be achieved: team ministry, days off and vacations. Presently, many ministers are of the opinion that they need to be continuously at work in the business of the church. Should they take time off from their busy schedules, they experience personal guilt and fear of criticism from their members. As a result, many ministers are overburdened, exhausting all their energies in performing pastoral duties, as well as those which other team members can perform.

These acts are all done in an effort to satisfy the conscience; however, such an approach can be detrimental to the minister's health. E. White (1925, p. 68) attests, "The idea that the minister must carry all the burdens and do all the work, is a great mistake. Overworked and broken down, he may go into the grave, when had the burden been shared as the Lord designed, he might have lived." 
To illustrate, the story of John Sanford's father is a perfect example of a minister who learned through experience the necessity of the wise use of energy for longevity in ministry. John tells how his father, an Episcopal minister in his later years of ministry, practiced energy conservation. Said Sanford (1982, pp. 17-18),

I remembered that he worked what seemed like endless hours. All day, most evenings, and often seven days a week he would labor at his parish duties. He was effective too: a respected priest, efficient rector, and a good pastor. But later in his life he changed." I remember that once he said to me, "I used to work all the time. Now I decide what is an honest day's work and do it and then go home. . My father's practical attitude toward his work day made life better for him-and his family-and enabled him to keep working as a priest all his life.

\section{Gift-based Ministry}

The key for the conservation of energy is not working "endlessly" but effectively. The minister's goals and visions must be accomplished through tactful planning and wise use of available resources. The work certainly never ends and neither can it be done by or with the minister's strength alone. It was never God's intention for the minister or anyone to perform this great task of ministry alone. Thus, God gave different gifts to the church. The Bible states, "And he gave some, apostles; and some, prophets; and some, evangelists; and some pastors and teachers; For the perfecting of the saints, for the work of the ministry, for the edifying of the body of Christ" (Eph 4:11-12).

One of the minister's roles as the overseer of the flock, therefore, is to harness these gifts and guide their use in the work of the Lord. In this regard, E. White (1952, p. 487) states,

Let the overseers of the church devise plans whereby young men and women may be trained to put to use their entrusted talents. ... Let ministers put to use all their ingenuity in devising plans whereby the younger members of the church may be led to co-operate with them in missionary work. But do not imagine that you can arouse their interest merely by preaching a long sermon.... Plan ways whereby a live 
interest may be kindled. Let all have a part to act.

Therefore, ministers can avoid overwork by developing gift-based ministries within congregations. Here, service is performed as a team where each member is put to work in a specified area of competency according to the individual gifts identified.

\section{Team Ministry}

Team ministry will provide the minister with numerous benefits, all contributing to conservation of energy. One such benefit is helping the minister remain focused on a principal responsibility, that is, feeding the flock with the Word. When ministers fail to perform ministry in the context of a team, they become absorbed in work which they may be incompetent to perform effectively, as well as become distracted from the focus on feeding the flock.

Hence, the Apostles of the early church promoted team ministry in order to conserve and direct their energies to their primary responsibility of feeding the flock. The Bible states, "Then the twelve called the multitude of the disciples unto them, and said, 'It is not reason that we should leave the word of God, and serve tables'" (Acts 6:2). Thereafter, the biblical account notes that the apostles then appointed deacons to perform the duties of serving tables while they remained attentive to the presentation of God's Word.

Another benefit of team ministry is that it spares the minister from a mind cluttered with matters that distract from the focal point of the ministry. E. White (1946, p. 91) speaks against the minister being burdened with tasks that are not part of his primary responsibilities, as she noted that "those who enter the ministry engage in a special work and should give themselves to prayer and to the speaking of the Word. God 
wants all their brain power to be used in proclaiming the gospel clearly and forcibly ..."

Once more, team ministry distributes the load of ministry among group members. Understanding that he is a team member (carrying responsibilities like every other member), the minister should resist the temptation to perform tasks that others are equipped to perform. Thus, longevity is secured due to a reduced work load, and adequate time to renew and conserve energy will be established, maintaining a constant momentum in ministry.

It must be underscored, however, that team ministry can only be successful, acquiring all its benefits in ministry, when the minister is an effective team player. According to C. White (1998, p. 189), the following are eight suggestions for ministers to be effective team players:

1. Personal presentation to others, e.g. by dress, general appearance and deportment.

2. Being open, e.g. not withholding information/transparency.

3. Being sensitive to others' needs and feelings.

4. Giving space for others to contribute.

5. Accepting criticism and not taking it personally.

6. Working with confidence.

7. Working to the best of our abilities.

8. Acknowledging (or, accepting responsibility for taking) the role of the leader.

\section{Taking a Day Off}

The ministry is not a call to work endlessly or harder than God expects. The example Jesus set pertaining to work is a perfect demonstration that one, even when working for the Master, must not engage in endless work. The Bible tells us in the book of Genesis that God worked six days and rested on the seventh day. God refused to work without rest. "And on the seventh day God ended his work which he had made; and he rested on the seventh day from all his work which he had made" (Gen 2:2). 
Likewise, a rest day/day off each week is central to the worker's need for revival and reenergizing. In ministry, however, while the seventh-day rest is observed, the minister finds himself attending to parish responsibilities as well as feeding the flock. Even though it is the Sabbath, the minister is mentally and physically exerting energy toward the fulfillment of flock-needs, and serving the church membership tends to be more demanding than on any other day.

Accordingly, the minister should set apart another day in the week for rest from his ministerial duties. The aim must be to seek a different experience as compared to the regular week day. A day off from ministerial duties allows the minister to reenergize and refocus to attend to the flock and his personal health. Such a day can only accomplish its purpose when $\mathrm{s} / \mathrm{he}$ refrains from regular, mundane activities.

In speaking of the nature of an effective day off, Sanford (1982, p. 19) states, "It is important that the day off (or two days off) be kept sacred, with none of the usual activities.... By removing yourself from your usual surroundings and task you allow a consciousness to take shape." The minister, as a result of having such a day, makes way for fresh thoughts and experiences.

Many ministers avoid taking meaningful rest from their districts because they are of the opinion that they must work continually since they are working for the Lord, and unless they perform the task, it cannot be done. They ignore the fact that they can only do so much. The human body has limits; it can only go thus far and no farther.

By the same token, many people become physically ill as they are inclined to push the body beyond its limits; this is known as overloading. Overloaded leaders are carrying responsibilities that amount to more than the ability and/or capacity to execute 
effectively; just as there may be physical, performance, emotional, and mental demands, similar categories of limits should be enforced (Swenson, 2004).

When ministers keep taking on numerous responsibilities and keep serving the flock without rest, they are living without limits. The onus therefore lies with ministers to establish and guard their limits, being conscious of physical, mental and spiritual capacity. When a minister does not take time off to replenish, he is running the risk of exceeding his limits. Sanford (1982, p. 55) said, "Once we reach our limit, fatigue sets in, followed quickly by exhaustion and collapse." Thus, ministers give close attention to the old adage, "prevention is better than cure," and seek ways to slow down, to "stop and smell the roses."

\section{Vacation Time-Have Fun}

While striving for the Master, walking on the pathway to heaven, there needs to be a clear understanding of what it means to be like little children. Identify an old hobby, and rekindle the old "fun flames;" play games with the family--some cricket, jumping jacks, etc; go for walks in nature; take your spouse on a date; have fun dates with each child (with the child in charge); do a course for audit; go bird watching or star gazing; or be creative again and embark on a building project-build something. Do something different, something fun!

Be sure to embrace one of the greatest pleasures of life-laughter. Let humor be an integral part of life. Be sure to laugh-achieve the smile, the grin, the chuckle, the giggle, and remember the belly laugh, that is, the out loud, 'ear to ear' kind.

It follows that the minister needs to take meaningful and productive vacations. This period must be more than a weekly day off from the regular ministerial duties; it 
needs to be meaningful. While it is time away from the regular routine of ministry, vacations must serve toward the development of the individual in his capacity as a person. Therefore, it must be well-planned for the accomplishment of a desired purpose, a learning experience, for example, a short mission trip, a fun and educational conference, a visit to a childhood home town or embarking on a special study. Any vacation, whether spent at home, far or near, can serve to refresh the minister and bolster service to others.

\section{Others' Expectations}

The minister must not try to live up to everyone's expectations. When a minister is assigned to a congregation, members have their individual and collective expectations of him. Here, Zomermaand (2006, par. 3) states, "As pastors serve others they are very vulnerable to the temptation to overdo, over achieve, over compensate, and over care for others."

The temptation to overdo comes because of the belief that every request must be attended to since the members expect us to. Zomermaand (2006, par. 5) aptly puts it,

This temptation comes in the form of the tentative knock on the door and the timid query, "Pastor, can I talk to you about something?" It comes in the form of the phone call in the middle of the night informing the pastor that a close relative of a parishioner has died tragically, and asking "Could you go to inform the family?" It comes in the form of a council member seeking the pastor's advice on a serious issue in his family. "Could we keep this just between us, pastor? I don't want my family to know I spoke with you about this. .." Most pastors are very capable of handling these appropriately. But others have gotten to the point where their coping abilities are so worn down that they fall victim to the temptation to over do, over care, etc.

Surely, it is impossible for the minister to acquire all the needed abilities, talents, etc. to satisfy or live up to everyone's expectation. Unless the minister becomes realistic 
and accepts the fact that $\mathrm{s} / \mathrm{he}$ cannot be all things to all men, s/he will be a victim of burnout.

Members' expectations come with many demands on the minister. These demands, in one way or the other, call for the minister to exert physical, mental or spiritual energy. The minister must therefore be mindful of not over-exhausting him/her self.

Still, there are means by which the minister can maintain a balance between the expectations of members and his capacity to live up to them: (1) The minister should clarify the expectations that the administrative body of the congregation has of him. (2) The minister needs to be knowledgeable of personal competencies, understand personal limitations, and be quick to identify the tasks that $\mathrm{s} / \mathrm{he}$ is and is not capable of performing.

Clearly making it known when an expectation falls outside personal competencies is a means of avoiding the burden of living up to an unrealistic expectation or having members disappointed when the minister is not true to his word. It is always within the realm of honesty for the minister to say, "my time will not allow me to ...; I do not have the same opinion about ...; I am unable to ..." Sincerity is, indeed, an durable strategy.

\section{Presentation 5: Preventing Burnout Through \\ Enrichment of the Spiritual Disciplines}

Introduction

The spiritual disciplines of prayer, meditation, and study are key to the minister's renewal of spiritual energy. Meditation was a discipline that Bible characters such as Isaac and Jesus practiced in order to be in contact with God. These men stepped away 
from their daily activities of giving physically, mentally and spiritually to others in order to receive and be revived both physically and spiritually. They utilized places such as the fields and deserts for their meditation. Thus, "Isaac went out to meditate in the field at the eventide: . $\therefore$ " (Gen 24:63). Jesus was no stranger to taking time to meditate on his Father: "when Jesus heard of it, he departed thence by ship into a desert place apart: . .." (Matt 14:13).

\section{Content of Presentation 5}

Devotional. "And in the morning, rising up a great while before day, he went out, and departed into a solitary place, and there prayed" (Mark 1:35, KJV). Key Point: Amidst the demands of ministry, personal encounters with God are necessary.

Preventing burnout through enrichment of the spiritual disciplines. Spiritual discipline of meditation. Spiritual discipline of prayer.

Activity Break. Open discussion. Personal experiences: What has worked for you as a spiritual discipline for renewal? In what way(s) has it been beneficial to you in preventing burnout?

Preventing burnout through enrichment of the spiritual disciplines. Spiritual discipline of study.

Prayer Clusters. Divide into groups of three or four. Sharing prayer requests. Three or four short prayers for cluster members.

When Joshua, Moses' minister, was given the responsibility of Israel's leadership at the death of Moses, the disciplines of meditation and study were recommended to him by God for his success and prosperity as a leader:

Now after the death of Moses the servant of the LORD it came to pass, that the 
LORD spake unto Joshua ... saying .... Only be thou strong and very courageous, that thou mayest observe to do according to all the law .... This book of the law shall not depart out of thy mouth; but thou shalt meditate therein day and night, that thou mayest observe to do according to all that is written therein: for then thou shalt make thy way prosperous, and then thou shalt have good success (Josh 1:1).

Among the many guidelines given to Joshua, the minister, by God was to know the book of the law and meditate on its content. To know God's law, he needed to be a student of the word. Then, to meditate means he needed to spend time alone, reflecting on God's Word, thus thinking of ways in which he could apply them to his life as a model to God's people.

Likewise, E. White (1967) spoke of meditation upon Jesus in her personal life as a means of strengthening her soul as food did for her physical body. Her personal experiences of the benefits of meditation led her to encourage ministers to do the same in order to ensure that their spiritual life be secure in Christ. She said, "You must meditate, you must pray, you must examine yourself in the light of God's Word. . . When I think of one who has preached the truth to others becoming a castaway, my soul is stirred with anguish" (E. White, 1890, p. 41).

Furthermore, Foster (1998) speaks of the inward spiritual disciplines of meditation, prayer, and study as a means of reenergizing and equipping the child of God for service. He speaks of meditation as when the servant of God shuts him/herself away from the normal routine of life and allocates time to listen to God, reflect on his works, rehearse his deeds, ruminate on his laws, etc. In actuality, meditation brings one into closeness with God.

Yet another spiritual discipline, prayer, is vital in the face of an imminent threat of burnout. Prayer is the minister's source of renewed strength. One authority, Hulme 
(1985, p. 59), said of this discipline:

... when our lungs in both body and spirit are constricted by stress, prayer is a way of getting our breath because it opens to our perspective the possibilities of hope. When we pray, we enter the realm of the Spirit, which is not confined to the constriction created by stress. Prayer facilitates the leap of faith in the direction of God in whom. these possibilities exist.

Many ministers are so busy taking care of feeding the flock spiritually that they do not have time for meaningful prayer. While some know the importance of prayer, but just cannot find the time to pray, others view it as time wasted. The truth, however, is that when time is not spent in prayer; the spiritual energy is deprived of being recharged or revived.

Even the great reformer, Martin Luther, described his life as one of daily busyness. However, in order to receive strength to accomplish his many tasks and maintain his spirituality, quality time was spent in meaningful prayer. He said, "I have so much business I cannot get on without spending three hours daily in prayer" (Foster, 1998, p. 34).

Similarly, ministers ought to be conscious of the fact that their ministry involves leading the flock in spiritual warfare. Thus, the minister can become drained spiritually due to encounters with spiritual issues and demonic forces. The minister, therefore, must spend quality and meaningful time in prayer, for spiritual battles can only be won in the spiritual realm.

Next, the spiritual discipline of study should be cultivated along with those mentioned above. There is need for a cognitive restructuring of the minds of many ministers. One's thoughts can contribute to burnout. Being positive and optimistic contributes to a happy and healthy life. Being negative, on the other hand, gives the 
opposite result. It is essential, therefore, that the minister think positively and rebuke negative thoughts in his ministry. A popular Mahatma Gandhi quote in Misra (1995, p. 149) declares, "A man is but the product of his thoughts. What he thinks, he becomes."

Therefore, study of the Bible strengthens the minister's trust in God, from whom the minister receives guidance and instructions. The nature of pastoral work can cause the minister to have many fears and doubts that can impact the way s/he serves. Fear of not being accepted by the people served, fear of not being able to live up to his/her expectations, fear of not being a worthy vessel to carry out God's directives, fear of not being a successful leader, fear of failure, etc. can lead to a minister's anxiety and overwork. On the contrary, Foster (1998, p. 62) states, "Many Christians remain in bondage to fears and anxieties simply because they do not avail themselves of the discipline of study."

Indeed, one can be set free from his/her thoughts of fear through the study of God's Word, for this very Word says, "And ye shall know the truth, and the truth shall make you free" (John 8:32). Preaching, experiencing a high in worship, or being superficially "holy" among the brethren cannot set the minister free. Only knowledge of the truth will set the minister free from the lies of failure that the devil seeks to impress upon the mind.

Accordingly, Croucher (2003) suggests that the study of the Bible will equip a minister with the tools needed to avoid burnout. Ministers are thus encouraged to be involved in identification of personal gifts and limits and, on the whole, seek to be a growing person. If God has further light and truth to break forth from his Word, each 
minister needs to ask the personal question: what new insights have I experienced recently?

\title{
Presentation 6: Congregational Role for the Prevention of Burnout
}

\author{
Introduction
}

The ministry is a very demanding service that utilizes spiritual, physical, and emotional energy. Here, members of the church as well as members of the community call upon the minister daily to attend to their various needs: The temptation is always there for the minister to overwork in an effort to effectively meet these demands, becoming fatigued in the process.

Bob Zomermaand, a minister in the United States, gives his personal experience as it relates to overwork. He wanted to attend to the needs of every member that sought his service. As a result, he became a victim of the compassion fatigue form of burnout.

Therefore, he noted: "I became fatigued in my spirit, in my emotions, and in my body. I had overdone it all. As a result, I lost my ability to be a useful tool in the Lord's hand. I was finally diagnosed with something I had never heard of: compassion fatigue" (Zomermaand, 2006, par. 7).

This is a malady that affects those who serve in the helping vocations such as clergy, and is a condition that hinders the performance of one's professional duties. Ministers become victims of burnout as a result of stretching themselves, overworking, in an effort to meet the demands of the church.

The church therefore, can play a major role of supporting the minister in avoiding of burnout. 


\section{Content of Presentation 6}

Devotional. "And it came to pass, when Moses held up his hand, that Israel prevailed: and when he let down his hand, Amalek prevailed. But Moses' hands were heavy; and they took a stone, and put it under him, and he sat thereon; and Aaron and Hur stayed up his hands, the one on the one side, and the other on the other side; and his hands were steady until the going down of the sun. And Joshua discomfited Amalek and his people with the edge of the sword (Exodus 17:11-13, KJV). Key Point: The laity ought to be willing to hold up the clergy's hand in support of God's cause.

\section{Congregational role for the prevention of burnout.}

Activity Break. Round Table Discussions-Encourage participants to join in a circular seating arrangement. Suggested open-ended questions: Do the church and its members help to cause compassion fatigue and burnout among ministers? If yes, how so? If no, elaborate as well. What can individuals and/or the church do to assist in the prevention of compassion fatigue among clergy? What factors may prevent individuals and/or the church from being willing to assist in this regard? Answering Guideline: THINK (allow 2 minutes of silence when individual participants can think about and note possible responses); SHARE (sharing thoughts in 'round table' discussion).

There are ways in which the church can play a role in this regard. After a period of tragedy within the church family and the minister's extended focus on walking that family, individual, etc., through the turmoil, s/he can be encouraged to seek a breather, and/or, the church may choose to sponsor a retreat or sabbatical as a means of ensuring that $\mathrm{s} /$ he follows through. This is needed since, as a helper, $\mathrm{s} /$ he has shared some of the wounds of the wounded, and may need a spiritual and physical refresher. 
In addition, church boards and members need to require ministers to designate a day for communion with God, a day for personal spiritual renewal. A burnout survivor, Zomermaand (2006, par. 10) declared that in treating burnout, "one of the best 'cures' is the deepening of one's spiritual roots. Too often the overwhelmed pastor does not have enough time to go deep with God."

Another area of focus should be sensitivity to the ministerial family and its needs. Many well-meaning members seek to buttress the minister's wife and children by offering tangible support when they sense that s/he is engrossed with congregational responsibilities. These acts of kindness go a long way in bringing comfort to the burdened family. In addition, ministers can share experiences with members who have been 'family supporters', calling the home to encourage and pray with spouse and children, and even visiting the home (both in the minister's presence and absence) to assist with household chores and childcare. Here, the sensitivity of these well-meaning members will guide them in decisions to prevent intrusion, and overstaying one's welcome where the family is concerned.

In every instance, be creative. Every church develops a working knowledge of its minister and has an idea of what makes him/her 'tick'. Indulge him/her every so often with something special, a dinner, special health care, etc. Every congregation can seek, under God's directive, to assist in the preservation of the health and well-being of its minister and ministerial family, thus reducing the incidence of burnout.

\section{Conclusion}

In conclusion, I have witnessed many of my colleagues in the Guyana Conference as they began ministry all full of zeal and with great success stories. However, after a 
few years, many simply go through the motion of ministry with the evidence of burnout. As a result, their health, families and congregations have shared in his struggles, both directly and indirectly.

Many ministers cannot explain why they cannot function as they should, why they are so negative and even angry all the time with members, family members and even their administrators. They even complain of not seeing meaningful results for their labors, even though they claim to continue to work as hard as they did. After all, they have become victims of burnout.

Thus, this series is mainly designed to equip ministers with the knowledge needed to avoid burnout by being able to, as Sanford (1982) suggested, work harder and even more effectively than previously, but never endlessly. I also recommend that these presentations be utilized by ministers as well as other leaders in Christian ministries or other helping professions. Furthermore, to achieve maximum results, the presentations should be coupled with the accompanying activities which may be altered as needed. 


\section{CHAPTER 6}

\section{RECOMMENDATIONS AND CONCLUSION}

The purpose of this project was to design contextual seminars for Seventh-day Adventist ministers in Guyana on the prevention of and recovery from burnout and compassion fatigue. No research has been previously done on this subject in the Guyana Conference even though these phenomena continue to be of great concern. Thus, the purpose of this project was developed to increase awareness of the phenomenon as well as to aid ministers in dealing with the effects of burnout and compassion fatigue due to the demands of ministry in this part of the vineyard, the Guyana Conference of SDA.

The repercussion of the effects of this phenomenon can go from the minister's family as far as his feelings of his personal standing with God. In highlighting the impact of burnout in the life of ministers, Perry $(1982$, p. 17) states,

I believe that those in 'full-time Christian work' face the heaviest decisions in the matter of burnout. When a pastor or missionary or youth leader burns out and leaves the ministry, he disappoints not only his wife, his children, his parents, his congregation, fellow pastors, seminary professors, and the whole denomination. $\mathrm{He}$ believes he surely has disappointed God!

\section{Statement of Conclusion-General Issues}

By and large, work expectations of ministers in Guyana contribute to and advance the incidence of burnout. In this conference, where ministers have been assigned to as many as twenty-one church districts, unrelieved ministry stress which is reflective of 
burnout, is conceivable. While shepherding these churches, the conference administrators demand and expect achievements and ministry performance equal to the service rendered in a one to two church district.

Even though ministers are called to a lifetime of ministry, such administrative requirements cater for short-term performance. The minister may attempt to fulfill such demands for a limited time since; s/he may lack the physical, spiritual and mental fortitude that service amidst long-term stress necessitates. Ministers soon discover that the work is never-ending and the results are not as rapid and readily seen as expected. As a result of constantly over-working in the quest for results, $\mathrm{s} / \mathrm{he}$ experiences burnout.

At the same time, the compassion fatigue aspect of burnout exists among ministers as a result of attending to members who are victims of various traumatic events. Often times, ministers are not trained to attend to such individuals and are not provided with the resources, for example, continued education in the area of counseling, to be equipped to do so. This further increases the minister's proclivity to the incidence of burnout.

\section{Expectations from Project}

Balance is necessary in every aspect of the human life. In view of that, Swenson (2004, p. 183) notes that "we each are made up of trillions upon trillions of working units .... Yet everything must function in balance. If this balance is disturbed, disease is the result. We get sick. We feel pain .... It is no different in the broader context of life."

Similarly, the pursuit of excellence in concert with striving to achieve goals set by one's congregation and administrators can lead to an imbalanced life for the minister. Such ministers may derive success and a feeling of fulfillment in one area of life while 
the others suffer. Thus, one authority states,

While undivided devotion to one cause can bring great success and vault a person into prominence, such a priority structure often leaves the rest of that person's life in a state of disorder. Thus it is not uncommon to discover a physician who fails as a parent, an entertainer who fails as a spouse, a pastor who neglects personal health, or an executive who fails at all those areas. Traditional wisdom has told us not to ... all our eggs in one basket. Yet, in pursuit of excellence, we often discard this basic wisdom. Balance is not the goal; preeminence is the goal (Swenson, 2004, p.185).

Ministers therefore, must seek to be proportionate in their service, avoiding the temptation to be obsessed with achieving parish goals while neglecting physical health, family, recreation and other aspects of holistic development. Distinction in one sphere of life should not be allowed to cause the demise of another.

Indeed, the call to ministry is not only a call to serve others but also one's self. It was the Bible writer, Paul who said, "I keep under my body, and bring it into subjection: lest that by any means, when I have preached to others, I myself should be a castaway" (1 Cor. 9:27). Thus, the entire gospel, which proclaims holistic health-physical, spiritual, mental, social-must not only be preached to others, but also lived by those who proclaim it. The minister is expected to live what he preaches.

Therefore, ministers balance their ministry to others as well as to themselves when they resist the temptation to overdo or over work. The Mayo Clinic Dictionary (2008, par. 3) defines burnout as "a state of physical, emotional and mental exhaustion caused by long-term exposure to demanding work situations. Burnout is the cumulative result of stress."

As is seen in the life of many church leaders, including James White, such exhaustion that leads to burnout comes when the worker is so engaged in his work that he lacks balance between work and personal life. Ponder (1983, p. 12) describes the victim 
of burnout as "hardworking and dedicated, sincere and loyal."

The bottom line here is that ministers need to decide what constitutes an honest day's work, and perform it. In adition, s/he needs to change the methodology of leadership to one of empowerment and team work. Such an approach to ministry will preclude overwork and result in preserving the minister's overall health. Willimon (1989, p. 58) states that "while we have seen that burnout and dissipation of the Spirit is a problem shared by clergy and laity alike, the pastor's own leadership and initiative are crucial in the care of this problem. First, the pastor must display personal and time management habits that demonstrate to the laity that church commitments must be balanced with personal renewal and spiritual growth".

In addition, ministers' leadership methodology of being lone rangers-being everything to everyone, contributes to burnout. Thus, team ministry and the delegation of responsibility are necessary to prevent and deal with these phenomena. This is the method Jethro introduced to Moses and also the leadership model portrayed by Jesus. One author notes that with large districts, pastors need to set specific priorities and enforce them (Willimon, 1989).

Then again, ministers need to assess their service throughout every aspect of their ministry, decide where others can serve effectively, and delegate responsibilities. The question should ever be, "Is there a parishioner who is competent and willing enough to perform this task?" This is essential in the development of team ministry since the laity may be deprived of service opportunities if the minister attempts to function in every capacity.

On the conference level, the administrators are the ones who are responsible for 
giving the ministers their assignments in the field. Thus, it is important for them to be aware of the effects of and preventive measures for burnout in an effort to supervise ministers effectively. Having a clear knowledge of these phenomena will guide the administration toward reducing the workloads where necessary, in addition to equipping ministers with the tools necessary to serve in the Guyana context. In the long-term, ministers will be better able to maintain good health and move towards longevity and more effective service.

Additionally, tools for ministers' longevity and effective service would include such things as continued education, visits to counselors, and improved working conditions. The aim of the administrators, therefore, would be both to accomplish organizational goals and visions and to preserve ministers as they develop to serve to the best of their abilities.

In fact, administrators need to be mindful of an approach which may sanction ministers' preoccupation with success to the extent that they are constantly functioning at the limit, overdoing and overworking. Should ministers always be busy attending to the needs of their parish and working endlessly to meet unrealistic administration goals, they will surely not last. Swenson (2004, pp. 195-196) made a comparison of human beings and vehicles in an effort to demonstrate the dangers of constantly pushing oneself in the area of work. He states that,

...the healthiest lifestyle comes equipped with four gears: The first gear is park for the contemplative times. This gear is used for rest and renewal, and to recharge our batteries. This is where we do much of our thinking about values and spirituality, as well as our study and prayer. ... The second gear is low. This gear is for relationships, for family and friends. This is the gear we use when talking with someone and it prevents us from being distracted and nervously moving on to the next activity while still in the middle of a conversation. This is the gear we use when the children ask for a story or a back rub.... The third gear is drive. This is our 
usual gear for work and play. This gear uses lots of energy, and the faster speed feels good because it is productive. It gets us from place to place quickly.... The forth gear is overdrive. This gear is reserved for times that require extra effort. If we have a deadline coming, we kick into this gear.

The truth is that all the gears mentioned are essential and are a part of our lives. However, as ministers, we ought to be able to change gears and not operate constantly in 'overdrive' as in the Guyana context of ministry. Staying in overdrive will make one vulnerable to illness and burnout. Swenson (2004, p. 196) said, "Unfortunately, many in our society do not shift down from overdrive. Our cars are not meant to race at high speeds continuously. Neither are our bodies or spirits. Yet to slow down for some is unthinkable for some and for others, impossible".

Finally, it must be noted that victims of burnout experience great difficulties in functioning effectively on their jobs. Figley $(2002$, p. 7$)$ highlighted the following signs of burnout in the work performance of victims: "low morale; low motivation; avoiding tasks; obsession about details; apathy; negativity; lack of appreciation; detachment; poor work commitments; staff conflicts; absenteeism; exhaustion; irritability; withdrawal from colleagues." In fact, any minister exhibiting these signs in his service will be ineffective and consequently, will not perform nor motivate his congregation to perform exceptionally well.

Thus, clergy deal with burnout in various ways. Some change professions, some migrate to other fields, and others remain in the ministry in the Guyana field due to personal circumstances. However, while those who leave may be forgotten, those who remain, in some instances, as in the case of burnout victims, are vulnerable to health complications and engender negative effects for those with whom they interact and serve. Perry (1982, pp. 26-27) notes that "many burnout victims wish they could quit their 
stress-related jobs but for the sake of fear of failure, security, or loyalty to loved ones, they remain as bitter herbs in the lives of others." As ministers are aware of and strive to address this phenomenon, there is much hope for prevention of the same.

\section{Recommendations}

Notably, a pastor shepherding multiple congregations--as many as twenty churches-is a recipe for burnout. Such a large volume of work carried out by one minister is, in reality, assigning to the minister the work of several ministers. Thus, the minister is given a task that requires more energy than he may possess and is vulnerable to burnout if systems are not put in place to aid in the replenishing of energy and the prevention of persistent overwork. Sanford (1982, pp. 103-104) asserts that, "burnout is related to the symbolism of fire, and that fire is a form of energy...Clearly if energy is constantly undergoing entropy the world is running down, just as a human being who only dissipates energy will run down."

Furthermore, it is imperative that the minister master ways of replenishing energy in an attempt to advance endurance, as well as, to function effectively. Here, Rediger (1997, p. 137) points out that "energy and its management is another resource and skill critical to healthy pastoring, whether a pastor is under attack or not. . . Clergy killers can distract pastors into dissipating their energies into hopeless worry and fighting."

Accordingly, burnout among clergy in the Guyana conference must be attended to by a collaborative effort of conference administrators, ministers in the field and the local congregations. The following are recommendations that are not solutions to burnout by themselves, but can accomplish the task of minimizing the phenomenon while encouraging effective service. 
Initially, the administrator should focus on employing a variety of techniques designed to motivate and encourage ministers to produce, as opposed to coercive methods. Ministers must never feel that they have to overwork and over-extend themselves in order to produce for fear of failure. One of the ways this can be accomplished is through the utilization of training programs and the creation of a team building atmosphere that will not allow for a few to receive the praises and rewards, but allows for all to feel significant and pivotal in the accomplishment of shared goals.

Equally important is the need for the administrator to provide resources for ministers to develop professional competence. These competencies can be realized through various means of continued education, with the understanding that generations and the world as a whole continue to change rapidly. As a result, ministers encounter an express turnover of new challenges in ministry. These challenges can prove fatal to the minister if not dealt with appropriately. Rediger (1997, p. 137) affirms that "excellence in ministry is a noble and satisfying goal. Pastors are more vulnerable to clergy killers and to loss of support and failure when they fail to learn and grow and improve."

Next in significance to the above recommendations is the need for the ministerial secretary to motivate support groups comprised of professional consultants for ministers. Such consultants can include counselors, social workers, and/or retired as well as current experienced ministers who are trained and capable of providing support to ministers when required.

Even so, the administrator should seek to create work conditions that are less stressful for ministers. Such conditions would include reducing the number of churches in districts. This can be done by training laity and assigning them to churches as lay 
pastors. According to one burnout authority, cumulative job stress accounts for instances of burnout in the work environment (Lehr, 2006). Vernon Zunker (2006, p. 480) further notes ten stressful work conditions:

...conditions of work: unpleasant work environment, necessity to work fast, excessive and inconvenient hours; work itself: perception of job as uninteresting, repetitious, overloaded, and demanding; shifts: rotating shifts affecting bodily functions and role behaviors; supervision: unclear job demands, close supervision with no autonomy, scant feedback from supervisors; wage and promotion: inadequate income; role ambiguity: lack of clarity about one's job and scope of responsibilities; career development stressors: little job security, impending obsolescence, dissatisfaction over career aspirations and current level of attainment; group stressors: insufficient group cohesiveness, poor group identity in the organization; organizational climate: impersonally structured organizational policies; organizational structure: too bureaucratic or too autocratic .

Next, the overall work load of ministers should be reduced to levels that prevent work overload.

Additionally, the transactional model of leadership portrayed in the Guyana Conference should be altered to one of a transformational model to facilitate reduced job stress and to foster team ministry. Collegial conversations reveal that ministers' monthly earnings are threatened to be withheld when reports are not submitted at specified times; rewards are distributed at the workers' party to 'successful' ministers; and in some cases, ministers are transferred to districts based on the minister's rate of accomplishment, rather than a match to meet the particular district's needs. Such leadership characteristics are typical of the transactional model of leadership—which seeks to influence performance through threats owing to poor functioning, and rewards for good behavior (Bass, 1990).

It follows that the model of leadership required in Guyana is one that will seek to create a work environment which is less stressful as administrators and ministers work 
together in an influential relationship, towards a shared goal. Such is found in the transformational model of leadership.

In drawing a comparison between the transactional and transformational models of leadership, Northouse $(2004$, p. 11) states, "When compared to transactional leadership, which has a focus on the exchanges that occur between a leader and his or her followers, transformational leadership looks at the process in which an individual engages with others and creates a connection that raises the level of motivation in both the leader and followers."

Furthermore, Kouzes and Posner (2007) highlighted five practice characteristics of the transformational leadership approach: modeling the way; inspiring a shared vision; challenging the process; enabling others to act; and encouraging the heart. These transformational leadership characteristics, if practiced in the Guyana Conference, will foster team ministry and thus, minimize burnout. In such teams, members are actively inspiring, motivating, empathizing with and empowering each other.

It must be noted however, that due to the vastness of the field and the geography of the country, team work that transformational leadership proposes can only achieve maximum success in the context of virtual teams since virtual teams allow members to work in partnership through electronic communications means (Chinowsky \& Rojas, 2003). Although ministers are shepherding large districts and are separated by land and seas, they can still work successfully as a team.

\section{Summary}

As has been noted, ministers are at great risk of being victims of compassion burnout. The nature of ministry in Guyana Conference is one in which a minister is 
assigned to numerous churches simultaneously. Thus, the minister is expected to attend to the needs of each church and each member while maintaining his responsibility as priest of his home.

Such work overloads coupled with the minister's motivation to be a successful pastor drives him/her, in many cases, to overwork. In the process of overworking, they tend to stretch themselves beyond their margins-physical and spiritual capacity. Consequently, they are at risk of becoming victims of burnout.

In fact, I am very optimistic that this series of burnout presentations will serve to equip ministers with an improved understanding of this phenomenon and prepare them to identify signs and symptoms as well as to seek means of prevention.

Many ministers are of the delusion that they are immune to these problems since they are servants of God, the Great Provider and Sustainer. Chapter 2 seeks to eliminate this mental model by highlighting the experiences of biblical characters, such as Elijah and even the pioneer, James White, who were victims of this phenomenon. The fact is that while we are unique individuals, our physical energy has its limitations. Also found in the sacred pages of scripture are examples of effective ways of preventing the incidence of burnout.

Often, the lack of a clear understanding of the reality of this problem among clergy further complicates it since many ministers are not aware of this ministry interrupter and its confounding details. Knowledge has always proven to be the best prevention to many of life's catastrophes. Thus, should ministers become more knowledgeable of the nature and devastating effects of this phenomenon about themselves and their ministry, they could avoid becoming victims. 
The purpose of chapter 3 is to provide readers with the available facts presented by authorities in the fields of research. While the term burnout has been known in almost every profession since it is related to the depletion of one's energy, the term compassion fatigue has been discovered to affect mainly individuals in the helping professions and comprises signs and symptoms that are similar to burnout. Thus, in many cases-in the helping professions-they are used interchangeably.

Furthermore, Chapter 4 seeks to convey the challenge of shepherding large districts and its contributions to burnout. The main contributors to this concern are the work environment and its demands. Thus, having ministers overloaded with numerous congregations and members as in the Guyana context sets the stage for burnout.

As has been noted, burnout seldom intrudes upon the lives of victims suddenly; neither is it inescapable. There are signs and symptoms that the minister can detect and take note when his health is shifting in directions that lead to burnout. Also, there are numerous ways in which burnout can be prevented. Chapter 5 explains the signs of burnout and compassion fatigue. Thereafter, simple preventive measures are suggested for ministers to manage work and health towards the maintenance of healthy, productive ministries.

On the whole, the call to ministry is neither fleeting nor temporary; instead, it is permanent. It is the service of a lifetime. Health—both physical and spiritual-is needed for a minister to endure in this lifetime of service. S/he therefore cannot afford to work without pacing him/herself to finish the race. For this reason, the ministry calls for the wise use of resources-not only those available in the form of human personnel who may be utilized through team ministry, but also the minister's energy. As was noted earlier, 
this project contains tools that will equip the minister to be effective in ministry while maintaining longevity.

\section{Recommendations for Further Research}

This project sought to highlight and address burnout mainly in the context of pastoral ministry in the Guyana conference of SDA. However, in light of the fact that the SDA organization is a worldwide movement and similarities in parish ministry cuts across denominational lines, I hasten to point out that a number of interesting research questions can be generated from this research as an aid to ministers beyond the scope of this project's focus, as they attend to unique burnout circumstances.

Relevant follow-up research questions first include how the SDA organizational structure and standards for placing value on results contribute to burnout among clergy. This study would provide for a thorough examination of the effects of the actual model of leadership practiced by the SDA organization, that is, the transactional model-as opposed to transformational model.

A second research question of interest is what issues on a global church scale need to be addressed to assist in the healthy functioning of clergy. One such issue is the pay scale of ministers. Though each field has its own unique economy and needs, the local conference does not determine the pay scale and other benefits for ministers in its fields. Thus, those in the particular field may be in a better position to plan for the best interests of its clergy.

Finally, how does the lack of full-time ministerial secretaries dedicated to the growth and support of pastors (rather than supervising them for higher productivity) affect the ministry? For a number of years, the president of the Guyana Conference 
carried dual roles of ministerial secretary and conference president. Such situations have negative repercussions because ministers may not feel free to seek needed help for fear of the consequences of such a dual relationship, for example, the president's view/perception of him may become discolored.

Evidently, this project opens many doors for further research angles among issues of clergy burnout. A mixed methods research with a larger sample could show some interesting characteristics; an examination of Seventh-day Adventist clergy in a number of conferences-in both developed and third world countries-could show some key variances. Here, an emphasis could also be placed on tracking and comparing major differences and similarities in the incidence of the phenomenon across countries/conferences.

As more research projects are conducted and more leaders who are struggling with symptoms of burnout are identified, their common as well as varying characteristics could be viewed as models. Ultimately, these studies could aid in motivating better leadership actions and more effective and efficient pastoral districts and conferences. 
APPENDIX A

MAPS 


\section{Map of South America}

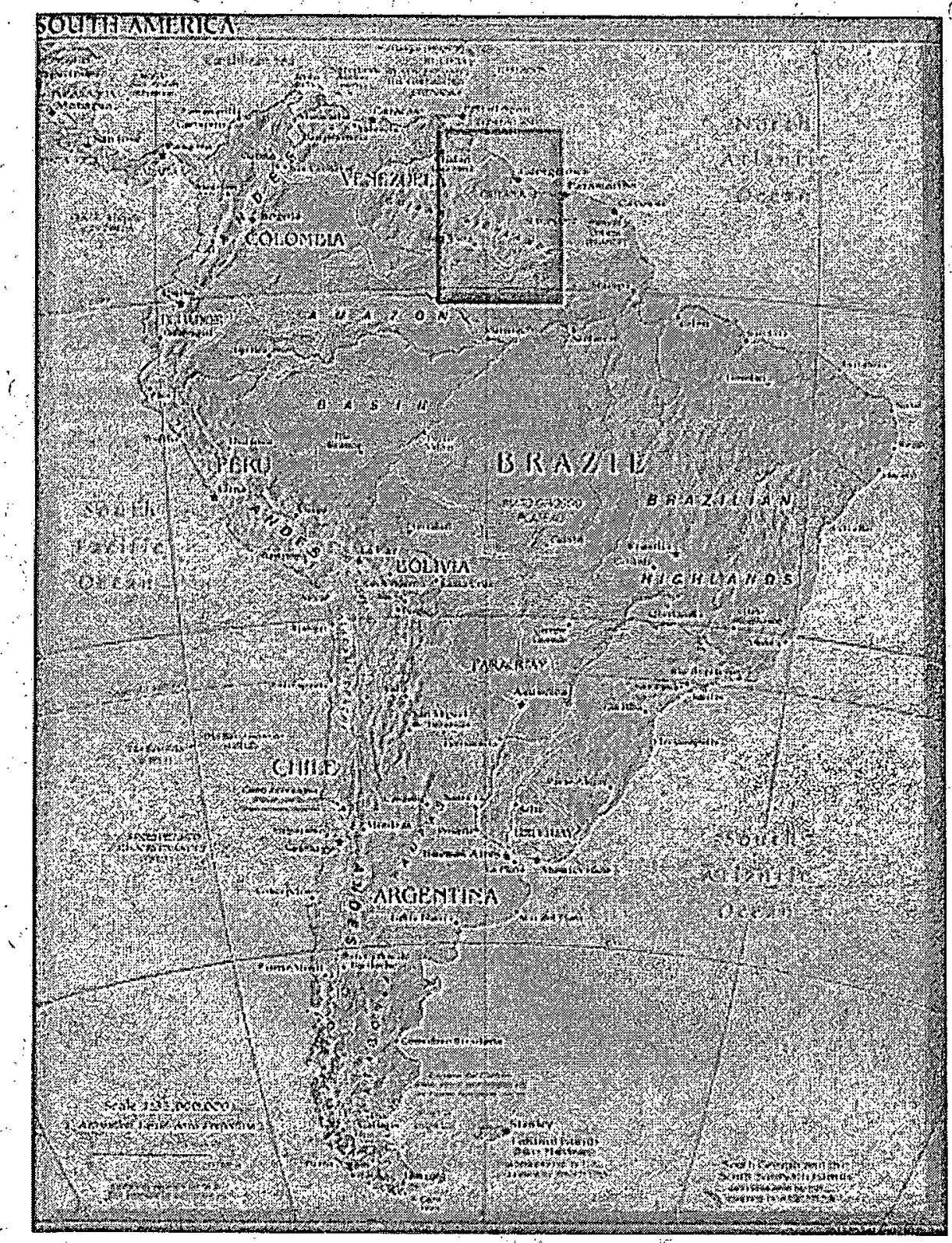


Map of South America with Guyana Highlighted

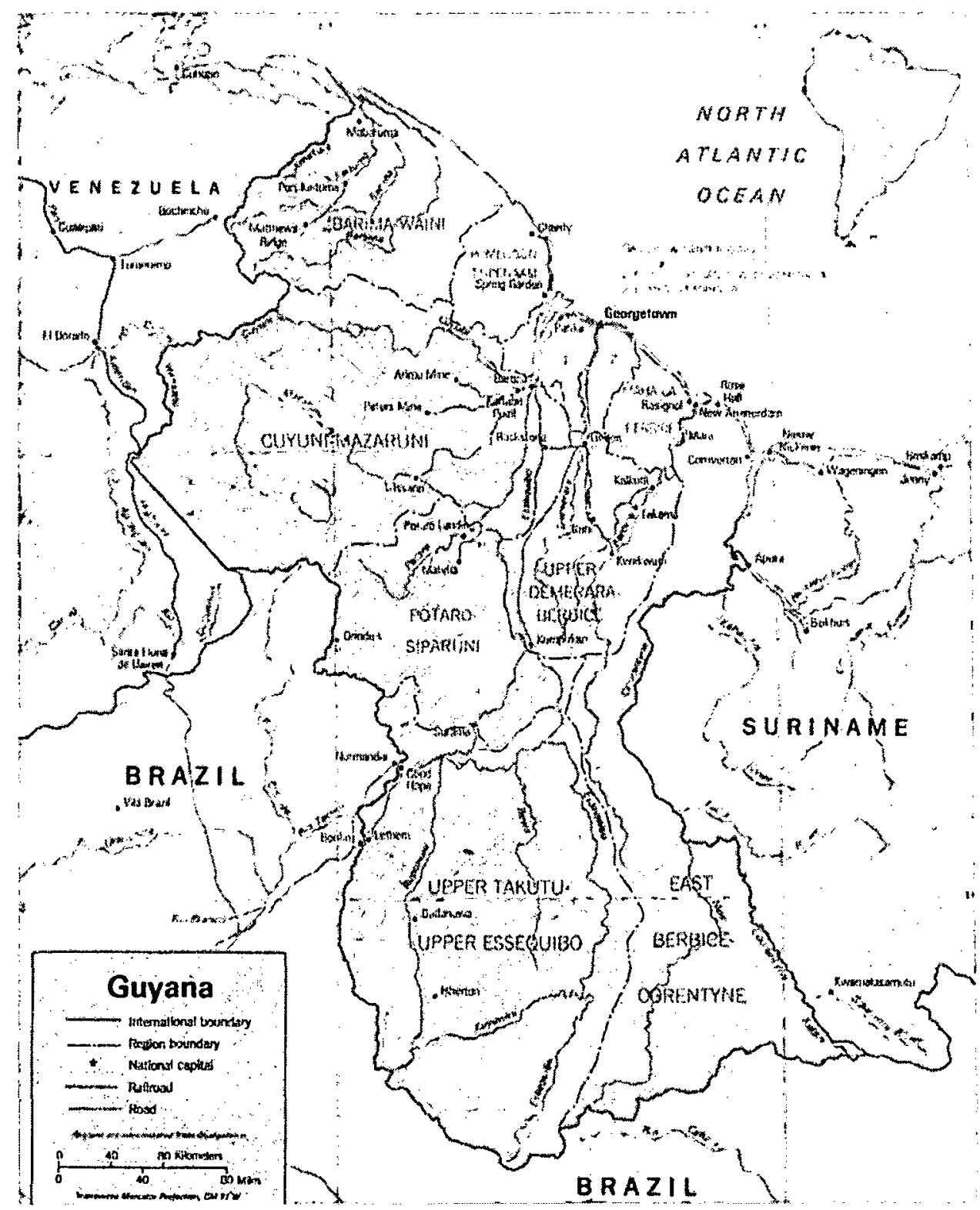


APPENDIX B

TABLES 


\section{Table 1}

The Growing Membership and Fluctuating Clergy Numbers Over the Period 1997-2006

\begin{tabular}{cccc}
\hline Year & Membership & Ordained Ministers & Licensed Ministers \\
\hline 1997 & 34,301 & 18 & 15 \\
1998 & 35,635 & 12 & 13 \\
1999 & 36,973 & 11 & 11 \\
2000 & 39,004 & 11 & 11 \\
2001 & 40,471 & 14 & 10 \\
2002 & 42,548 & 14 & 11 \\
2003 & 43,657 & 15 & 10 \\
2004 & 45,739 & 15 & 6 \\
2005 & 47,331 & 22 & 6 \\
2006 & 50,040 & 21 & 4
\end{tabular}


Table 2

The Ratio of Pastors to Members Over the Period 1997-2006

\begin{tabular}{cc}
\hline Year & \multicolumn{2}{c}{ Ratio of Ministers to Members } \\
\hline 1997 & $1: 1039$ \\
1998 & $1: 1425$ \\
1999 & $1: 1607$ \\
2000 & $1: 1773$ \\
2001 & $1: 1619$ \\
2002 & $1: 1773$ \\
2003 & $1: 1679$ \\
2004 & $1: 1829$ \\
2005 & $1: 1820$ \\
2006 & $1: 1853$
\end{tabular}


Table 3

The Number of Ministers Leaving Ministry in the Guyana Conference Over the Period 1997-2006

\begin{tabular}{ccc}
\hline Year & Ordained Ministers & Licensed Ministers \\
\hline 1997 & 0 & 0 \\
1998 & 6 & 2 \\
1999 & 1 & 1 \\
2000 & 0 & 1 \\
2001 & 0 & 0 \\
2002 & 0 & 1 \\
2003 & 0 & 0 \\
2004 & 0 & 0 \\
2005 & 0 & 1 \\
2006 & 1 & 0
\end{tabular}




\section{REFERENCE LIST}

American Psychiatric Association (2000). Diagnostic and statistical manual of mental disorders, (4th ed., rev.). Washington, DC: American Psychiatric Association.

Anderson, R. S. (2001). The shape of practical theology. Downers Grove, IL: InterVarsity Press.

Baird, S., \& Jenkins, S. R. (2003). Vicarious traumatization, secondary traumatic stress, and burnout in sexual assault and domestic violence agency volunteer and paid staff. Violence and Victims, 18, 71-86.

Ballis, P. H. (1999). Leaving the Adventist ministry: A study of the process of exiting Westport, CT: Praeger.

Barton, J. \& Muddiman, J. (2001). Oxford Bible commentary. Oxford; New York: Oxford University Press.

Bass, B. M. (1985). Leadership and performance beyond expectations. New York: Free Press.

Bass, B.M. (1990). From transactional to transformational leadership: Learning to share the vision. Organizational Dynamics, 18, 19-31.

Bass, B. M \& Avolio, B. J. (Eds.). (1994). Improving organizational effectiveness: Through transformational leadership. Thousand Oaks, CA: Sage Publications. 
Bass, B. M., Avolio, B. J., Jung, D. I., and Berson, Y. (2003). Predicting unit performance by assessing transformational and transactional leadership. Journal of Applied Psychology, 88 (2), 207-218.

Battiste, V. (2007). Treat compassion fatigue. Retrieved April16, 2008, from http://www.wcr.ab.ca/news/2008/0602/fatigue060208.shtml.

Beaton, R. D. \& Murphy, S. A. (1995). Working with people in crisis: research implication. In C.F. Figley (Ed.), Compassion fatigue: Coping with secondary traumatic stress disorder in those who treat the traumatized. New York: Brunner/Mazel.

Bernard, L. L. (1926). An introduction to social psychology. New York: Henry Holt. Beyersdorf, A. R. (1997). The pastor's time management in the light of the divine call. D.Min. diss., Concordia Theological Seminary.

Bibleworks Software (2006). The Matthew Henry commentary.

Boscarino, J. A., Figley, C. R., \& Adams, R. E. (2004). Evidence of compassion fatigue following the September 11 terrorist attacks: A study of secondary trauma among New York City Social Workers. Journal of Emergency Mental Health, 6 (2).

Brady, J. L., Guy, J. D., Poelstra, P. L., \& Brokaw, B. F. (1999). Vicarious traumatization, spirituality and the treatment of sexual abuse survivors: A national survey of women psychotherapists. Professional. Psychology, Research and Practice, 30, 386-393.

Brattberg, G. (2006). PTSD and ADHD: Underlying factors in many cases of burnout.Stress and Health, 22 (5), 305-313.

Burns, J. M. (1978). Leadership. New York: Harper and Row. 
Burns, J.M. (2003). Transforming leadership. New York, NY: Atlantic Monthly Press.Buttrick, D. (1994). A captive voice: The liberation of preaching. Louisville, KY: Westminster/John Knox Press.

Carroll, J. W. (1991). As one with authority: Reflective leadership in ministry. Louisville, KY: Westminster/John Knox Press.

Carroll, J. W. (2001). Reflections of a clergy watcher. Durham, NC: Duke University Divinity School.

Carson, D. A. (1984). The feeding of the five thousand. In The expositor's Bible commentary (Vol. 8, p. 341). Grand Rapids: Zondervan.

Carson, D. A. \& Moo, Douglas J. (2005). An introduction to the New Testament. Grand Rapids, MI: Zondervan.

Chilson, A. (1991). The 'Davis' Indians. Adventist Review. Retrieved July 10, 2008 from http://guyanaconference.org/article.php?id=41

Chinowsky, P. S. \& Rojas, E. M. (2003). Virtual teams: Guide to successful implementation. Journal of Management in Engineering, 19 (3), 98-106.

Chrestman, K. R. (1995). Secondary exposure to trauma and self reported distress among therapists. In B.H. Stamm (Ed.), Secondary traumatic stress: Self care issues for clinicians, researchers, and educators, pp. 29-36. Lutherville, MD: Sidran Press.

Country Studies Program. Guyana. Economy. Retrieved from http://www.countrystudies.com/guyana/economy.html

Croucher, R. (2003). Stress and burnout in ministry. Retrieved March 31, 2008 from http://www.churchlink.com.au/ churchlink/forum/r croucher/stress burnout.html. Currid, J. D. (2001). A study commentary on Exodus. Auburn, MA: Evangelical Press. 
Danieli, Y. (1988). Treating survivor and children of survivors of the Nazi Holocaust. In F. Ochberg (Ed.), Post-traumatic therapy and victims of violence, pp. 278-294. NY: Brunner/Mazel.

Darby, J. (1867). Commentary on Mark 6. John Darby's synopsis of the New Testament. Retrieved from http://www.searchgodsword.org/com/dsn/view.cgi?book=mr\& chapter $=006$.

Davey, J. (1995). Burnout: Stress in the ministry. Leominster, England: Gracewing. De Graaf, J. (2003). Take back your time: Fighting overwork and time poverty in America. San Francisco, CA: Berrett-Koehler.

Dick, D. R. \& Miller, B. (2001). Equipped for every good work: Building a gifts-based church. Nashville, TN: Discipleship Resources.

Edwards, W. D. (2003). A Study on various factors and their relationship to burnout among Seventh-day Adventist clergy. Berrien Springs, MI: Andrews University.

Edwards, A. \& Wilson, J. R. (2004). Implementing virtual teams: A guide to organizational and human factors. Aldershot, England: Gower.

Eisner, E. W. (1998). The enlightened eye: Qualitative inquiry and the enhancement of educational practice. Upper Saddle River, NJ: Merrill.

Elwell, W. A. (2002). Baker commentary on the Bible. Grand Rapids, MI: Baker.

Faulkner, B. R. (1981). Burnout in ministry. Nashville, TN: Broadman Press.

Feig, R. (1995). Construct validation of time management within the five factor model of personality. Ph.D. diss., Hofstra University.

Figley, C. R. (Ed.). (1985). Trauma and its wake, volume I: The study and treatment of post-traumatic stress disorder. NY: Brunner/Mazel. 
Figley, C. R. (Ed.) (1986). Trauma and its wake: volume 2: Post-traumatic stress disorder: Theory, Research, and Treatment. NY: Brunner/Mazel.

Figley, C. R. (1989). Helping traumatized families. San Francisco: Jossey-Bass.

Figley, C. R. (Ed.). (1989). Treating stress in families. NY: Brunner/Mazel.

Figley, C. R. (1995a). Compassion fatigue: Coping with secondary traumatic stress disorder in those who treat the traumatized. Bristol, PA: Brunner/Mazel.

Figley, C. R. (1995b). Compassion fatigue: Toward a new understanding of the costs of caring. In B.H. Stamm (Ed.), Secondary traumatic stress: self-care issues for clinicians, researchers, and educators, (pp. 3-28). Lutherville, MD: Sidran Press.

Figley, C. R. (1997). Burnout in families: The systemic costs of caring. Boca Raton: CRC Press.

Figley, C. R. (2002). Compassion fatigue and the psychotherapist's chronic lack of self care. Journal of Clinical Psychology, 58 (11), 1433-1441.

Fisher, D. (1996). The 21st century pastor: A vision based on the ministry of Paul. Grand Rapids, MI: Zondervan.

Foster, R. J. (1998). Celebration of discipline. New York, NY. HarperCollins.

Francis, L. J. \& Jones, S. H. (1996). Psychological perspectives on Christian ministry : A reader. Leominster, Herefordshire: Gracewing.

Freudenberger, H. J. \& Richelson, G. (1980). Burnout: The high cost of high achievement. MA: Anchor Press.

Fuller R. \& Daléne C. (2002). Pastoral care for post-traumatic stress disorder: Healing the shattered soul. New York: Haworth Pastoral Press. 
Funk, J. R. (2005). Balancing the burdens of caregiving: Avoiding compassion fatigue. Chaplaincy Commentary. Retrieved February 24, 2008, from http://www. hcmachaplains.org/commentary2.html

Furst, S., Reeves, M., Rosen, B., \& Blackburn, R. (2004). Managing the life cycle of virtual teams. Academy of Management Executive, 19 (2), 6-19.

Gaebelein, F. E. (1981). Expositor's Bible commentary (Vol. 4). Grand Rapids, MI: Zondervan.

Ghahramanlou, M. \& Brodbeck, C. (2000). Predictors of secondary trauma in sexual assault trauma counselors. International Journal of Emergency Mental Health, 2, 229-240.

Gibson, C. B \& Cohen, S. G. (2003). Virtual teams that work: Creating conditions for virtual team effectiveness. San Francisco, CA: Jossey-Bass.

Gill, J. (2006). Commentary on Mark 6:7. John Gill's exposition of the Bible. Retrieved 2008, from http://bible.crosswalk.com/Commentaries/GillsExpositionoftheBible /gil.cgi?book $=\mathrm{mr} \&$ chapter $=006 \& v e r s e=007$.

Graen, G. (1976). Role-making processes within complex organizations. In M. D. Dunnette (Ed.), Handbook of industrial and organizational psychology. Chicago: Rand McNally.

Green, I. (1991). SDA Church in Guyana. Retrieved from http://guyanaconference. org/article.php?id=18.

Greenleaf, R. K. (2002). Servant leadership. Mahwah, NJ: Paulist Press.

Guyana Bureau of Statistics (2009). Census, $2001 \& 2002$. Retrieved from www. statisticsguyana.gov.gy. 
Guyana Conference of SDA Statistics. General Conference of Seventh-day Adventistworld church statistics. Retrieved on March 09, 2008, from http://www. adventiststatistics.org/view_Summary.asp?FieldInstID $=807268$.

Guyana (2006). Conference Statistical Report. Retrieved from http://guyanaconference.org/article.

Hall, J., Johnson, S., Wysocki, A., \& Kepner, K. (2002). Transformational leadership: The transformation of managers and associates. Retrieved from http://edis.ifas.ufl.edu.

Halpin, A. W., \& Winer, B. J. (1957). A factorial study of the leader behavior description. In R. M. Stogdill and A. E. Coons (Eds.), Leader behavior: Its . description and measurement. Columbus, $\mathrm{OH}$ : Bureau of Business Research, Ohio State University.

Henry, Matthew. (2003). The Matthew Henry commentary [CD-ROM]. Bibleworks Software.

Hart, A. (2003). Burnout. http://www.alc.edu.au/alconline/PAS1018/Topic\%201\%20 Self-care\%20for\%20pastoral\%20people/BURNOUT.htm

Herrington, J., Creech, R. R., \& Taylor, T. (2003). The leader's journey. San Francisco, CA: Jossey-Bass.

Hersey, P., Blanchard, K. H., \& Johnson, D. E. (1996). Management of organizational behavior: Utilizing human resources. $7^{\text {th }}$ ed. Englewood Cliffs, NJ: Prentice-Hall. Holden, P. (1998). The excellent manager's companion. Brookfield, VT: Gower.

Holder, S. (2007). Right here in the Americas-Political oppression in Guyana. Retrieved from http://www.afcguyana.com/html/latest_news_79.html 
Hulme, W. E. (1985). Managing stress in ministry. New York, NY: Harper and Row.

Johnson, C. N. E. \& Hunter, M. (1997). Vicarious traumatization in counselors working in the New South Wales Sexual Assault Service: An exploratory study. Work and Stress, 11, 319-328.

Jones, J.W. (1993). High-speed management: Time-based strategies for mangers and organizations. San Francisco, CA: Jossey-Bass.

Josephs, R. (1992). How to gain an extra hour every day. New York, NY: A Plume Book.

Kassam-Adams, N. (1995). The risks of treating sexual trauma: Stress and secondary trauma in psychotherapists. In B. H. Stamm (Ed.), Secondary traumatic stress: Self care issues for clinicians, researchers, and educators (pp: 37-47). Lutherville, MD: Sidran Press.

Kelly, M. L. (2003). Academic advisers as transformational leaders. The mentor. Retrieved from http://www.psu.edu/dus/mentor/030101mk.htm.

Klobas, J. E. \& Jackson, P. D. (2008). Becoming virtual: Knowledge management and transformation of the distributed organization. New York: Physica-Verlag.

Knight, G. R. (1993). Anticipating the advent: A brief history of Seventh-day Adventists. Boise, ID: Pacific Press.

Kouzes, J. \& Posner, B. (2002). The leadership challenge. $3^{\text {rd }}$ ed. San Francisco: JosseyBass.

Kouzes, J.M. \& Posner, B. Z. (2007). The leadership challenge. $4^{\text {th }}$ ed. San Francisco: Jossey-Bass.

Kumle, J. \& Kelly, N. J. (2006). Leadership vs. management. Supervision, 67 (8), 11-13. 
Langford, D. L. (1998). The pastor's family: The challenges of family life and pastoral responsibilities. New York: Haworth Pastoral Press.

Längle, A. (2003). Burnout: Existential meaning and possibilities of prevention. European Psychotherapy, 4 (1), 107-121.

Lehr, F. (2006). Clergy Burnout. Minneapolis: Fortress Press.

Lewis, D.A (1995). People-sensitive time management. Church Administration, 37, 38.

Liu, C. M. (1991). A spiritual model for recovery of pastors suffering burnout: The pine springs retreat. Unpublished Doctor of Ministry project, Andrews University, Berrien Spring, Michigan.

London, H.B. \& Wiseman, N. B. (2003). Pastors at greater risk. Ventura, CA: Regal Books.

Mackay, J. (2001). Exodus, a mentor commentary. Ross-shire, Great Britain: Christian Focus Publications.

Mackenzie, M. \& Mackenzie, A. (1995). Investing time for maximum return. West Des Moines, IA: American Media Publishing.

Macy, H. R, (1990). Just say no. Discipleship Journal, 10, 29-33.

Maiden, R. P. \& Thompson, C. (2006). Workplace disaster preparedness, response, and management. New York: Haworth Press.

Map of South America. Retrieved from http://www.rau.edu.uy/universidad /iaesteextranjeros/reception_booklet/images/south_america_pol98.jpg.

Maslach, C. (1982). Burnout: The cost of caring. Paramus, NJ: Prentice Hall. 
Maslach, C. (1993). Burnout: A multidimensional perspective. In W.B. Schaufeli, C. Maslach, \& T. Marek (Eds.), Professional burnout: recent developments in theory and research (pp.19-32). Washington, DC: Taylor \& Francis.

Maslach, C. \& Goldberg, J. (1998). Prevention of burnout: New perspectives. Applied and Preventative Psychology, 7 (1), 63-74.

Mayo Clinic Dictionary (2008). Retrieved from http://www.mayoclinic.com/health /burnout/WL00062.

McBride, J. L. (1998). Spiritual crisis: Surviving trauma to the soul. New York: Haworth Pastoral Press.

McBride, J. L. (2005). Living faithfully with disappointment in the church. Binghamton, NY: Haworth Pastoral Press.

McCann, I. L. \& Pearlman, L. A. (1990). Vicarious traumatization: A framework for understanding the psychological effects of working with victims. Journal of Traumatic Stress, 3, 131-149.

McCann, I. L. \& Saakvitne, K. W. (1995). Treating therapists with vicarious traumatization and secondary traumatic stress disorders. In C.R. Figley (Ed.), Compassion fatigue: Coping with secondary traumatic stress disorder in those who treat the traumatized. NY: Brunner/Mazel.

McHolm, F. (2006). Rx for compassion fatigue. Journal of Christian Nursing, 23 (4), $12-$ 19.

McKinley, S. (2003). Where does time go? In The time crunch: What to do when you can't do it all. Sisters, OR: Multnomah Books. 
McNeal, R. (2000). A work of heart: Understanding how God shapes spiritual leaders. San Francisco, CA: Jossey-Bass.

Miller, K. I., Ellis, B. H., \& Stiff, J. B. (1988). Communication and empathy as precursors to burnout among human service workers. Communication Monographs, 55 (9), 336-341.

Misir, P. (2008). Guyana and the world economy. Retrieved from http: //www.gina.gov.gy/archive/researchp/rpguyeconomy.html.

Misra, G. (1995). Psychological perspectives on stress and health. New Dehli, India: Concept.

Moeller, S. (1999). Compassion fatigue. New York: Routledge.

Mondros, J. B. \& Wilson, S. M. (1994). Organizing for power and empowerment. New York : Columbia University Press.

Morgenstern, J. (2004). Time management from the inside out: The foolproof system for Taking control of your schedule-and your life (2nd ed.). New York: Henry Holt/Owl Books.

Morrissette, P. J. (2004). The pain of helping : Psychological injury of helping professionals. New York: Brunner-Routledge.

Myers, S. M. \& Booth, A. (1999). Marital strains and marital quality: The role of high and low locus of control. Journal of Marriage and Family, 61, 423-436.

Nahavandi, A. (2003). The art and science of leadership. Upper Saddle River, NJ: Pearson Education.

Neils, H. (2008). Signs of burnout and how to help you avoid it. Retrieved from http://www.trans4mind.com/counterpoint/neils1.shtml. 
Nichol, F. D. (Ed.). Exodus. In Seventh-day Adventist Bible Commentary (Vol. 1). Washington DC: Review and Herald.

Northouse, P. (2004). Leadership: Theory and practice. Thousand Oaks, CA: Sage. Nurmi, R. \& Darling, J. R. (1997). International management leadership: The primary competitive advantage. New York: International Business Press.

Oden, T. C. (1983). Pastoral theology: Essentials of ministry. San Francisco: Harper \& Row.

Palmer, R.W. (1990). In search of a better life: Perspectives on migration from the Caribbean. New York, NY: Praeger.

Palmer, K. (2006). Miracles of Jesus Christ. Retrieved March 08, 2008, from www.LifeofChrist.com

Patte, D., et. al (ed.) (2004). Global Bible commentary. Nashville: Abingdon Press.

Patterson, J. M. (2002). Integrating family resilience theory and family stress theory. Journal of Marriage and Family, 64, 349-360.

Patterson, K. A. (2003). Servant leadership: A theoretical model. Doctoral dissertation, UMI No. 3082719, Regent University.

Pearlman, L. A. \& Saakvitne, K. W. (1995). Treating therapists with vicarious traumatization and secondary traumatic stress disorders. In C.R. Figley (Ed.), Compassion fatigue: Coping with secondary traumatic stress disorder in those who treat the traumatized. NY: Brunner/Mazel.

Perry, C. E. (1982). Why Christians Burnout. Nashville, TN: Thomas Nelson.

Perry-Jenkins, M., Repetti, R. L., \& Crouter, A. C. (2000). Work and the family in the 1990s. Journal of Marriage and the Family, 62, 981-998. 
Piantanida, M. \& Garman, N. B. (1999). The qualitative dissertation. Thousand Oaks, CA: Corwin Press.

Piccoli, G. \& Ives, B. (2003). Trust and the unintended effects of behavior control in virtual teams. Management Information Systems Quarterly, 27, 365-395.

Pines \& Aronson (1988). Burnout in families: The systemic costs of caring. In C.R. Figley (Ed.), Burnout. Boca Raton, FL: CRC Press.

Ponder, T. (1983). How to avoid burnout. Mountain View, CA: Pacific Press.

Powell, A., Piccoli, A., \& Ives, B. (2004). Virtual teams: A review of current literature and directions for future research. Database for Advances in Information Systems, $35(1), 6-36$.

Raleigh, W. (2007). The discovery of Guyana, South America. USA: Daniel Izzo.

Rayburn, C. A., Richmond, L. J., \& Rogers, L. (1986). Men, women, and religion: Stress within leadership roles. Journal of Clinical Psychology, 42, 540-546.

Rediger, G. L. (1982). Coping With clergy burnout. Valley Forge: Judson Press.

Rediger, G. L. (1997). Clergy killers: Guidance for pastors and congregations under attack. Louisville, KY: Westminster J. Knox Press.

Remer, R. \& Elliot, J. (1988). Characteristics of secondary victims of sexual assault. International Journal of Family Psychiatry, 9 (4), 373-387.

Renee, C. (1988). When helping you is hurting me. Harper Paperbacks.

Reynolds, R. (1999). Compassion fatigue: Worn out from caring. Littleton, CO: Serendipity House. 
Roberts, S. B., Flannelly, K. J., Weaver, A. J., \& Figley, C. R. (2003). Compassion fatigue among chaplains, clergy, and other respondents after September 11th. Journal of Nervous and Mental Disease, 191, 756-758.

Robertson, C. (2006). Offshore software development: The benefits and pitfalls of virtual teams. Retrieved from http://www.ideamarketers.com

Rosenberg, T. T. \& Pace, M. (2006). Burnout among mental health professionals: Special considerations for the marriage and family therapist. Journal of Marital and Family Therapy, 32 (1), 87-99.

Rost, J. C. (1993). Leadership for the twenty-first century. Westport, CT: Praeger.

Saal, F. E. \& Knight, P. A. (1988). Industrial/organizational psychology: Science and practice. Pacific Grove, CA: Brooks/Cole.

Sanford, J. A. (1982). Ministry burnout. New York: Paulist Press.

Scales, M., Coleman, L, Peace, R., \& Reynolds, R. (1990). Compassion fatigue: Worn out from caring. Littleton, $\mathrm{CO}$ : Serendipity Press.

Schaufeli, W. B., Maslach, C., \& Marek, T. (1993). Professional burnout: Recent developments in theory and research. Boca Raton, FL: CRC Press.

Schuster, M. A., Berq, S. H., Collins, R. L., Elliott, M. N., Jaycox, L. H., Kanhouse, D. E., Marshall, G. N., Morrison, J. L., Stein, B. D., \& Zhou, A. J. (2001). A national survey of stress reactions after the September 11, 2001, terrorist attacks. New England Journal of Medicine, 345 (20), pp. 1507-1512.

Sendjaya, S. \& Sarros, J. C. (2002). Servant leadership: Its origin, development, and application in organizations. Journal of Leadership and Organizational Studies, 9 (2), 57-64. 
Seventh-day Adventist Bible commentary series (CD-ROM). (2005). Hagerstown, MD: Review and Herald.

Seventh-day Adventist minister's manual. (1992). Silverspring, MD: The Ministerial Association, General Conference of Seventh-day Adventists.

Simic, I. (1998). Transformational leadership-the key to successful management of transformational organizational changes. Facta Universitas, 1 (6): 49-55.

Snyder, B. (2003). Teams that span time zones face new work rules. Retrieved from http://www.gsb.stanford.edu/news/bmag/sbsm0305/feature_virtual_teams.Shtml

Spears, L.C. (2004). Practicing servant leadership. Retrieved from http:// www.odl.rutgers.edu /eleadership/pdf/Servant\%20Leadership.PDF.

Stamm, B. H. (1997). Work-related secondary traumatic stress. PTSD Research Quarterly, (8) 2, Spring. Retrieved February 20, 2008 from http://www. dartmouth.edu/dms/ptsd/RQ_Spring_1997.html

Stamm, B. H. (2002). Measuring compassion satisfaction as well as fatigue: Developmental history of the compassion satisfaction and fatigue test. In C. R. Figley (Ed.), Treating compassion fatigue (pp. 107-122). NY: Brunner-Rutledge. Statistical Population Report. Guyana Bureau of Statistics, February 2009.

Staton, A. R., Benson, A. J., Briggs, M. K., Cowan, E., Echterling, L. G., Evans, W. F., McKee, J. E., Presbury, J., \& Stewart, A. L. (2007). Becoming a community counselor. Boston, MA: Lahaska Press.

Stevens-Guille, B. (2003). Compassion fatigue: Who cares for the caregivers? Retrieved May 06, 2008 from http://findarticles.com/p/articles/mi_qa3929 /is_200306/ai_n9260633. 
Stevenson-Moessner, J. (2005). Primer in pastoral care. Minneapolis: Fortress Press.

Stone, A. G., Russell, R. F., \& Patterson, K. (2003). Transformational versus servant leadership-a difference in leader focus. Servant Leadership Roundtable. Retrieved from http://www.regent.edu/acad/cls/2003servantleadershiproundtable /stone.pdf.

Swenson, R. A. (2004). Margin. Colarado Springs, CO: NavPress.

Suárez, L. M. \& Baker, B. L. (1997). Child externalizing behavior and parents' stress: The role of social support. Family Relations, 47, 373-381.

Tan, S. Y. (1991). Lay counseling : Equipping Christians for a helping ministry. Grand Rapids, MI: Zondervan.

The American heritage dictionary of the English language (4 $4^{\text {th }}$ ed.). (2003). Houghton Mifflin Company.

Tidwell, C.A. (1996). The Educational ministry of a church: A comprehensive model for students \& ministers. Nashville, TN: Broadman \& Holman.

Townley, C.T. (2009). The Innovation challenge: Transformational leadership in technological university libraries. Retrieved from http://www.iatul.org/ doclibrary/public/Conf_Proceedings/2009/Townleytext.pdf

Vakola, M. \& Wilson, I. E. (2004). The challenge of virtual organization: Critical success factors in dealing with constant change. Team Performance Management, 10 $(5 / 6), 112-120$.

Virtue, D. (1996). I'd change my life if I had more time: A practical guide to making dreams come true. Carlsbad, CA: Hay House. 
Walsh, F. (2002). A family resilience framework: Innovative practice applications. Family Relations, 51, 130-137.

Weaver, A. J., Kline, A. E., Koenig, H. G., Larson, D. B., Lucas, L. A., \& Samford, J. (1997). What do psychologists know about working with the clergy? An analysis of eight APA journals: 1991-1994. Professional Psychology: Research and Practice, 28, 471-474.

Weaver A. J., Koenig, H. G., \& Revilla, L. A. (2001). Counseling families across the stages of life: A handbook for pastors and other helping professionals. Nashville, TN: Abingdon Press.

Wee, D. \& Meyers, D. (2002). Response of mental health workers following disaster: The Oklahoma City bombing. In C. R. Figley (Ed.), Treating compassion fatigue. NY: Brunner/Routledge.

Weingarten, K. (2003). Common Shock: Witnessing Violence Every Day. New York: Dutton.

Weiser, C. (1994). Healers, harmed \& harmful. Minneapolis: Fortress.

Wells, B. (2002). Which way to clergy health? Divinity, 2 (1), 4-6

Wessel, W. W. Feeding of the five thousand. In The expositor's Bible commentary (Vol. 8, p. 672). Grand Rapids: Zondervan.

Wessells, D. T. (1989). Professional burnout in medicine and the helping professions. New York: Haworth Press.

White, C. P. (1998). The effective pastor. Rossshire, Great Britain: Christian Focus. White, E. G. (1875). Testimonies for the Church (Vol. 3) [CD-ROM]. Ellen G. White Writings Software, Complete Published Edition [2005]. 
White, E. G. (1877). The Spirit of Prophecy, (Vol. 2) [CD-ROM]. Ellen G. White Writings Software, Complete Published Edition [2005].

White, E. G. (1890). Testimonies on the Case of Elder E.P. Daniels [CD-ROM]. Ellen G. White Writings Software, Complete Published Edition [2005].

White, E. G. (1915). Gospel Workers [CD-ROM]. Ellen G. White Writings Software, Complete Published Edition [2005].

White, E. G. (1923). Counsels on Health [CD-ROM]. Ellen G. White Writings Software, Complete Published Edition [2005].

White, E. G. (1925). Christian Service. Washington, D.C.: Home Missionary Department of the General Conference of Seventh-day Adventists.

White, E. G. (1946). Evangelism [CD-ROM]. Ellen G. White Writings Software, Complete Published Edition [2005].

White, E. G. (1952). The Adventist Home [CD-ROM]. Ellen G. White Writings Software, Complete Published Edition [2005].

White, E. G. (1967). Christian Service [CD-ROM]. Ellen G. White Writings Software, Complete Published Edition [2005].

White, E. G. (1990). The Retirement Years [CD-ROM]. Ellen G. White Writings Software, Complete Published Edition [2005].

White, E. G. (1995): Pastoral Ministry. Maryland: Review and Herald.

White, E.G. (1997). Patriachs and Prophets. Coldwater, MI: Remnant Publications.

White, E. G. (2005). The Desire of Ages. Nampa, Idaho: Pacific Press Publishing Association. 
White, J. (2003). Life Incidents Adventist Classic Library. Berrien Springs, MI: Andrews University Press.

Wilkinson, B. (1999). Education-Guyana: "Brain-drain" afflicts nation's schools. Inter Press Service English News Wire. Retrieved from http://www.encyclopedia. com/doc/1P1-20894525.html

Willimon, W. H. (1989). Clergy and laity burnout. Nashville: Abingdon Press.

Wilson, J. P. \& Lindy, J. D. (1994). Countertransference in the treatment of PTSD. NY: Guilford.

Zimering, R., Munroe, J., \& Gulliver, S. B. (2003). Secondary traumatization in mental health care providers. Psychiatric Times, 20 (4), 1-6.

Zomermaand, B. (2006). Caring for pastors. The Christian Courier. Retrieved October 15, 2007, from http://www.divinity.duke.edu/programs/spe/articles/ 200610/caring.html

Zunker, V. (2006). Career counseling: A holistic approach ( $7^{\text {th }}$ Ed.). Belmont, CA: Brooks/Cole. 
VITA

Name: David Oliver McKenzie

Place of Birth: Georgetown, Guyana, South America

\section{Education:}

$\begin{array}{ll}2009 & \text { D.Min. } \\ 2008 & \text { M.A. } \\ 2006 & \text { M.Div.(equi.) } \\ 1999 & \text { B.A. }\end{array}$

2009

\section{Credentials}

2005
Leadership, Andrews University

Counseling, Andrews University

Andrews University

Theology (emphasis - Pastoral Ministry),

AU ext. campus of Caribbean Union College

Ministry/Professional Experience

$$
\begin{aligned}
& 2008-\text { Present } \\
& 2000-2008 \\
& 1997-1998 \\
& 1994-1995 \\
& 1993-1994
\end{aligned}
$$

Pastor, Northeastern Conf. of SDA, New York

Pastor, Guyana Conf. of SDA, Guyana

Literature Evangelist

Customs Clerk

Teacher

Awards

2001

2002

\section{Professional Membership}

2007-Present
Evangelist of the year

Evangelist of the year

Phi Lambda Theta International Honor Society and Professional Association in Education 